\title{
Plasticity in the Adult Human Oligodendrocyte Lineage
}

\author{
Nitin Gogate, ${ }^{1, a}$ Lalit Verma, ${ }^{1, b}$ Jia Min Zhou,, Elizabeth Milward, ${ }^{1}$ Ray Rusten, ${ }^{1}$ Michael O'Connor, ${ }^{3}$ Conrad \\ Kufta, ${ }^{2}$ Jin Kim, ${ }^{1}$ Lynn Hudson, ${ }^{1}$ and Monique Dubois-Dalcq ${ }^{1}$ \\ 'Laboratory of Viral and Molecular Pathogenesis and 'Neurosurgery Branch, National Institute of Neurological Disorders \\ and Stroke, National Institutes of Health, Bethesda, Maryland 20892 and ${ }^{3}$ The Graduate Hospital of the University of \\ Pennsylvania, Philadelphia, Pennsylvania
}

Preoligodendrocytes have been described in cultures and tissue prints of adult human white matter (Armstrong et al., 1992). To characterize further these precursors of human oligodendrocytes, we have investigated whether they express genes playing a critical role in oligodendrocyte development. In the intact human brain, platelet-derived growth factor receptor $\alpha$ (PDGF $\alpha \mathbf{R})$ and myelin transcription factor 1 (MyTI) transcripts are expressed in 1-2\% of cells of the oligodendrocyte lineage (OL), and clusters of such cells can be found in the periventricular region. Myelin basic protein transcripts containing exon 2 information (exon $2+\mathrm{MBP}$ ), which are characteristic of the premyelinating stage, are detected in $15-20 \%$ of OL cells in vivo. When OL cells are separated from human white matter and allowed to regenerate in vitro, a much larger proportion of these cells express developmentally regulated genes, while exon 2- MBP and proteolipid protein (PLP) transcripts characteristic of mature OL cells appear transiently downregulated. Basic fibroblast growth factor (bFGF), even in the presence of PDGF, does not promote DNA synthesis in these cultured OL cells. Yet bFGF induces human oligodendrocytes to regenerate their processes rapidly in vitro and to express 04 antigens as well as exon 2+ MBP, MyTI, and PLP transcripts. While bFGF accelerates early regenerative processes, it also maintains high expression of exon 2+ MBP transcripts in OL cells for up to 2 weeks in vitro. In contrast, high levels of insulin in the absence of bFGF allow accumulation of exon 2- MBP and PLP transcripts in most OL cells at 2-3 weeks in vitro. We propose that the myelinated human brain harbors a small pool of precursors of oligodendrocytes and that growth factor-regulated phenotypic plasticity rather than mitogenic potential accounts for the regeneration of oligodendrocytes in the initial stages of demyelinating diseases such as multiple sclerosis.

\footnotetext{
Received July 22, 1993; revised Nov. 30, 1993; accepted Jan. 4, 1994.

N.G. and L.V. were supported by the Myelin Project, Washington, DC, while pcrforming this work. We thank Dr. Steve Schiff(Children's Hospital, Washington, DC) and Dr. W. W. Tourtelotte and colleagues (National Neurological Research Specimen Bank, Los Angeles, CA) for supplying the control CNS tissues. Dr. Bill Richardson and Nigel Pringle kindly provided the PDGF $\alpha$ R probes. We are very grateful to Dr. Scott Young for his advice on the in situ hybridization technique, to Drs. Cedric Raine and Randall McKinnon for advice and permission to cite their unpublished data, and to Drs. Heinz Arnheiter and Ulrike Tontsch for their critical comments. Editing work was done by Pauline Ballew and Claire Gibson.

Correspondence should be addressed to M. Dubois-Dalcq, LVMP, Building 36 , Room 5D04, NINDS, NIH, Bethesda, MD 20892.

"Present address: Department of Neurology, University of Maryland, Baltimore, MD.

"Present address: School of Medicine, University of Maryland, Baltimore, MD. Copyright (C) 1994 Society for Neuroscience $0270-6474 / 94 / 144571-17 \$ 05.00 / 0$
}

IKey words: human brain, oligodendrocytes, regeneration, myelin genes, developmentally regulated genes $P D G F \alpha R$ and MyTI, basic fibroblast growth factor, in situ hybridization]

In the mammalian CNS, oligodend rocytes synthesize the myelin sheaths that enwrap most CNS axons and allow rapid and efficient conduction of impulses along the nerve tracts (Ritchie, 1984). In demyelinating diseases caused by viral infection or autoimmune reaction, multifocal loss of myelin results in neurological dysfunction of varying severity (Alvord et al., 1992; Fazakerley and Buchmeier, 1992). However, oligodendrocytes can regenerate, form new myelin sheaths around the denuded axons, and restore their function (Raine et al., 1988; Ludwin, 1989; Dubois-Dalcq and Armstrong, 1990). This repair process appears more efficient in rodents than humans, although remyelination can be observed in humans in the months following the development of lesions in multiple sclerosis (MS), a major neurological disease of temperate countries (Prineas et al., 1993). To clucidate the mechanisms of regeneration of CNS myelin in humans, we studied the biology of the oligodendrocyte lineage of the adult human brain in vivo and in vitro.

The origin of the oligodendrocytes has been extensively studied in the rat, where they originate from a precursor cell often called the O-2A progenitor (Raff et al., 1983; Levison and Goldman, 1993; reviewed in Raff, 1989; Richardson et al., 1990). Such progenitors give rise to either oligodendrocytes $(O)$ or type 2 astrocytes (2A) in vitro (e.g., Cameron and Rakic, 1991; Hardy and Reynolds, 1991; Dubois-Dalcq and Armstrong, 1992; Pfeiffer et al., 1993). When O-2A progenitors are grafted in vivo, they become oligodendrocytes but not type 2 astrocytes (Espinosa de Los Monteros et al., 1993). O-2A progenitors have been isolated from all regions of the CNS and they bind antibodies to a subset of gangliosides (reviewed in Dubois-Dalcq and Armstrong, 1992). These progenitor cells are dividing, bipolar, and motile cells that evolve into multipolar progenitors or preoligodendroblasts that can be identified by $\mathrm{O} 4$ antibody staining (Sommer and Schachner, 1981; Pfeiffer et al.. 1993). Such O4+ progenitors then differentiate into oligodendrocytes expressing galactocerebroside (GC), the major glycolipid of myelin, and later, the major myelin proteins, MBP and proteolipid protein (PLP) (Dubois-Dalcq et al., 1986, 1987; reviewed in Hudson, 1990), as well as less abundant proteins such as $2^{\prime}, 3^{\prime}$-cyclic nucleotide 3 '-phosphohydrolase (CNP). In the adult rodent CNS, rare "adult" O-2A progenitors reacting with the $\mathrm{O} 4$ antibody (or preoligodendroblasts) can be isolated from optic nerve, spinal cord, cerebellum, and brain (ffrench-Constant and Raff, 1986; Armstrong et al., 1990a; Hunter and Bottenstein, 1991; Wood 
and Bunge, 1991; Levine et al., 1993). In the optic nerve, adult $\mathrm{O}-2 \mathrm{~A}$ progenitors differ from neonatal progenitors by their more complex shape, slower cell cycle, and migration speed in vitro (Wolswijk and Noble, 1989; Wren et al., 1992). Such cells can divide and generate new oligodendrocytes following demyelination in rodents (Ludwin, 1979; reviewed in Dubois-Dalcq and Armstrong, 1990).

Much less is known about the development and regeneration of the oligodendrocyte lineage in human. As subcortical white matter is sometimes removed in neurosurgical procedures for focal lesions not affecting white matter, cultures cnriched in human oligodendrocytes can be prepared from fresh CNS tissue (Armstrong et al., 1992; Yong and Antel, 1992). O4+ GCcells (called preoligodendrocytes; see below) were recently identified in such cultures and shown to progressively differentiate into oligodendrocytes (Armstrong et al., 1992). Rare cells reacting only with the $\mathrm{O} 4$ antibody were also detected in tissue prints of human white matter (Armstrong et al., 1992). While antibodies to glycolipids allow clear identification of oligodendrocyte progenitors in the nonmyelinated developing CNS (Warrington et al., 1993), their use on sections of myelinated white matter is less reliable and the exact function of these glycolipids in oligodendrocyte development is unknown.

We have therefore chosen to study the expression of genes that are developmentally regulated in precursor cells of the human oligodendrocyte lineage (OL). One gene involved in a signaling pathway cssential to $\mathrm{O}-2 \mathrm{~A}$ lineage development is the $\alpha$ receptor of platelet-derived growth factor (PDGF $\alpha$ R). PDGF $\alpha$ R is highly expressed in the developing brain and in rat neonatal $\mathrm{O}-2 \mathrm{~A}$ progenitors but is barely detectable on differentiated oligodendrocytes (Hart et al., 1989; McKinnon et al., 1990; Pringle et al., 1992). Another gene highly expressed in cultured rat neonatal O-2A progenitors is myelin transcription factor 1 (MyTI), a new zinc finger protein that binds to specific regions of the PLP promoter and may regulate the onset of the myelination program (Kim and Hudson, 1992; Armstrong et al., 1993). Finally, large myelin basic protein (MBP) transcripts containing exon 2 information (exon $2+\mathrm{MBP}$ ) are synthesized by rodent cells at a premyelinating stage and such transcripts are also detected in the developing human brain (Carson et al., 1983; Kristensson et al., 1986a; Kamholz et al., 1988; Jordan et al., 1989a; Jordan, 1990; Allinquant et al., 1991). These exon 2+ MBP transcripts are progressively replaced by alternatively spliced transcripts devoid of exon 2 sequences (exon 2- MBP) when myelination or remyelination proceeds. Simultaneously, PLP transcripts emerge in oligodendrocytes assembling myelin sheaths. Thus, analysis of expression of PDGF $\alpha$ R, MyTI, early and mature MBP isoforms, as well as PLP in human oligodendrocytes by in situ hybridization in vivo and in vitro should identify human OL cells at a precursor, premyelinating, or differentiated stage.

One other way to characterize functionally the cells of the human oligodendrocyte lineage is to study their response in vitro to growth factors known to promote growth and/or differentiation of rat progenitors (Armstrong et al., 1992). Platelet-derived growth factor (PDGF), a cytokine expressed by most neurons in vivo (Sasahara et al., 1991; Yeh et al., 1991), stimulates migration, mitosis, and survival of neonatal $\mathrm{O}-2 \mathrm{~A}$ progenitors in vitro and allows their timely differentiation into oligodendrocytes (Noble et al., 1988; Raff et al., 1988; Richardson et al., 1988; Armstrong et al., 1990h; Barres et al., 1992; McKinnon et al., 1993). bFGF is also a mitogen for neonatal oligodendro- cytes and their precursors (preoligodendroblasts) but blocks their differentiation (Eccleston and Silberberg, 1985; McKinnon et al., 1991), while insulin-like growth factor I (IGF-I) promotes oligodendrocyte survival and development and enhances myelination in transgenic mice (McMorris et al., 1986; McMorris and Dubois-Dalcq, 1988; Barres et al., 1992; Carson et al., 1993). In cultures of adult rat CNS, O-2A progenitors divide in response to $\mathrm{BFGF}$ and PDGF alone or in combination (Wolswijk et al., 1991, 1992; Vick and DeVries, 1992), while oligodendrocytes can divide in response to neuronal signals (Wood and Bunge, 1986). In contrast, in cultures of adult human brain, neither preoligodendrocytes (corresponding to the adult rat $\mathrm{O}-2 \mathrm{~A}$ progenitor) nor oligodendrocytes respond to PDGF and/or bFGF by mitosis (Yong et al., 1988; Armstrong et al., 1992). The human $\mathrm{O} 4+\mathrm{GC}$ - precursor was therefore named preoligodendrocyte rather than preoligodendroblast. bFGF favors the human preoligodendrocyte phenotype in vitro while IGF-I promotes differentiation of human oligodendrocytes (Armstrong et al., 1992). There has been no report so far that the adult human CNS harbors cells with properties of the rat $\mathrm{O}-2 \mathrm{~A}$ neonatal progenitor cells.

Here we present evidence that the human myelinated brain contains a discrete pool of oligodendrocyte precursor cells expressing PDGF $\alpha$ R and MyTI while a larger subpopulation of glial cells expresses exon 2+ MBP transcripts. These transcripts are more widely expressed in regenerating OL cells in vitro than in vivo. While bFGF and PDGF fail to induce DNA synthesis in OL cells, bFGF is a potent inducer of regeneration of processes and of expression of developmentally regulated genes in $\mathrm{O} 4+$ cells during the first week in vitro. Full maturation of cultured OL cells occurs after 2-3 weeks in the presence of high levels of insulin that trigger $\mathrm{IGF}-1$ receptor signaling. Thus, specific growth factors may enhance oligodendrocyte regeneration and remyelination by rcgulating phonotypic plasticity rather than mitogenic activity in OL cells of the adult human CNS.

\section{Materials and Methods}

Source of tissues and histopathology. Our observations are derived mostly from the study of temporal lobe white matter of epileptic patients (18 specimens, ages 13-51 years) undergoing surgery for intractable epilepsy. The tissue did not include the epileptic focus. All specimens of patients included in this study were studied histopathologically (by courtesy of Dr. Katz at NIH and the Pathology Department at the Graduate Hospital of the University of Pennsylvania). There was no abnormality detected in two cases, while 12 other cases showed mild to moderate subpial cortical and subcortical white matter gliosis. In this series of 18 patients, there were two cases of cortical spongiosis within the epileptic focus, one case of disorganization of cortical layers with possibility of gangliocytoma, and one case of perivascular foamy macrophages in gray and white matter (white matter cells of the latter case were cocultured with neurons as mentioned in the discussion). Oligodendrocytes cultured from the white matter from these four patients behaved similarly to those of the other patients, but these cases are not shown in the figures. There was no evidence of myelin breakdown or dysmyelination in any case studied here.

Control CNS tissue consists of cerebellum from a 5-year-old child that was resected to get access to a brainstem medulloblastoma (kindly provided by Dr. Steve Schiff at Children's Hospital, Washington, DC), and temporal lobe tissue obtained at autopsy (fresh frozen, 9-9.5 hr postmortem) from three individuals (ages 49-61 years) who died from non-neurological causes. This tissue was kindly provided by the $\mathrm{Na}$ tional Neurological Research Specimen Bank at the VA Wadsworth Medical center in Los Angeles (Dr. W. W. Tourtelotte). Most surgically resected tissue was obtained from patients enrolled in a study approved by the hospital internal review board.

The epileptic tissue was divided into gray and white matter and a portion of each was either immediately frozen on dry ice for cryostat sectioning or placed into Dulbecco's Modified Eagle's Medium (DMEM; 
GIBCO, Grand Island, NY) buffered with 25 mm HEPES (GIBCO) containing $50 \mu \mathrm{g} / \mathrm{ml}$ gentamicin (Whitaken, Walkersville, MD) for culturing. In some cases, cryostat sections of the fresh brain biopsy tissue were stained with antibody to CNP, kindly provided by $\mathrm{Dr} F$. A. McMorris, Philadelphia, following a published procedure (Vogel et al., 1988).

Culture of $O L$ cells. Primary cultures and cultures enriched in $\mathrm{OL}$ cells were established largely as described before by Armstrong et al. (1992). Briefly, the white matter tissue was dissociated first enzymatically and then mechanically in order to obtain a single cell suspension. The tissue was incubated at $37^{\circ} \mathrm{C}$ with sequential enzyme treatments, twice for $20 \mathrm{~min}$ with solution 1 and once for $15 \mathrm{~min}$ with solution 2 . Solution 1 consisted of $0.125 \%$ trypsin (GIBCO), $20 \mathrm{U} / \mathrm{ml}$ papain (Worthington, Freehold, NJ), and $0.02 \%$ collagenase type III (Worthington) in minimal essential medium with 25 mM HEPES buffer (MEM-HEPES buffer; GIBCO); solution 2 consisted of $0.05 \%$ trypsin, $0.02 \%$ EDTA (GIBCO), and $0.02 \%$ collagenase type III in MEM-HEPES. The enzymatically digested tissue was then put in a third solution $[20 \mu \mathrm{g} / \mathrm{ml}$ deoxyribonuclease I (DNase I) (Sigma, St. Louis, MO), $0.166 \%$ bovine serum albumin (BSA; Sigma), and 10\% fetal bovine serum (FBS; Hyclone, Logan, UT)] and mechanically dissociated through pipettes of decreasing bore diameter $(5 \mathrm{ml}, 10-20$ times; $1 \mathrm{ml}, 10-20$ times; and Pasteur pipette, 10-20 times). Cells were spun down (10 min at 1500 $\mathrm{rpm}$ ) and resuspended in DMEM with $10 \% \mathrm{FBS}$ at $8 \mathrm{ml} / \mathrm{mg}$ of tissue and plated as drops $(200 \mu \mathrm{l})$ on to $35 \mathrm{~mm}$ petri dishes that were precoated with $5 \mu \mathrm{g} / \mathrm{ml}$ poly-D-lysine (Sigma). After incubating cells for $2 \mathrm{hr}$ at $37^{\circ} \mathrm{C}$ to enhance cell attachment, $2 \mathrm{ml}$ of DMEM containing $10 \% \mathrm{FBS}$ was added to each dish. After $2 \mathrm{~d}$ in vitro, the floating cells were collected and reseeded at a density double that of the initial seeding. These cells were fed on the following day with $1 \%$ FBS in a defined medium [DMEM $+5 \mu \mathrm{g} / \mathrm{ml}$ insulin, $50 \mu \mathrm{g} / \mathrm{ml}$ transferrin, $30 \mathrm{~nm}$ selenium, $30 \mathrm{nM}$ triiodothyronine (all from Sigma), $1 \mathrm{~mm}$ sodium pyruvate (GIBCO), and 25 $\mu \mathrm{g} / \mathrm{ml}$ gentamicin; modified from Eccelston and Silberberg, 1985]. In a few experiments, the floating cells were collected after an additional day from these reseeded cultures, replated, and $2 \mathrm{~d}$ later fed as previously described.

Cultures of purified OL cells were established using the procedure of Yong and Antel (1992). Briefly, mechanically minced tissue $\left(<8 \mathrm{~mm}^{3}\right)$ was washed three times with phosphate-buffered saline (PBS) and incubated $30 \mathrm{~min}$ at $37^{\circ} \mathrm{C}$ with $0.125 \%$ trypsin, $20 \mu \mathrm{g} / \mathrm{ml}$ DNase I in MEM-HEPES buffer. After dissociation by pipette aspiration as above and filtration through nylon gauze (133 $\mu \mathrm{m}$ mesh), FBS was added to a final concentration of $2 \%$; cells were then collected by centrifugation $(10 \mathrm{~min}, 1200 \mathrm{rpm})$ and resuspended in PBS. After centrifugation (30 min, 15,000 rpm) through 30\% Percoll (Sigma), the viable cell layer between the myelin cap and the erythrocytes was collected, washed three times by centrifugation (10 min, $1200 \mathrm{rpm})$ with $10 \%$ FBS in DMEM, and plated at 3-8 $\times 10^{5} \mathrm{cells} / \mathrm{cm}^{2}$ in the same medium onto uncoated $25 \mathrm{~cm}^{2}$ flasks. Reseeding was performed into 1\% FBS in defined medium as already described.

Growt factors. Human platelet-derived growth factor A chain (PDGF AA) (R \& D Systems, Minneapolis, MN) and human basic fibroblast growth factor (bFGF; UBI, Lake Placid, NY) were added to the media, usually after the reseeding step at $2 \mathrm{~d}$ and occasionally from the start of the primary cultures. bFGF was used at 5 or $10 \mathrm{ng} / \mathrm{ml}$. In some experiments $0.5-50 \mathrm{ng} / \mathrm{ml}$ bFGF was added to the medium to determine if the effects were dose dependent, and in other experiments a mixture of PDGF A $\Lambda$ and bFGF (both at $10 \mathrm{ng} / \mathrm{ml}$ ) was used and compared to PDGF AA or bFGF alone at the same dose. The effects of the growth factors were assayed in the defined medium previously described; however, $50 \mathrm{ng} / \mathrm{ml}$ insulin (referred to in the text as low insulin) was sometimes used instead of $5 \mu / \mathrm{ml}$ of insulin (referred to in the text as high insulin). Every 2-3 d the growth factors were replenished at the same dose. Mitogenic activity of the growth factors was tested by adding ${ }^{3} \mathrm{H}$ thymidine to the cultures for $2-7 \mathrm{~d}$ before fixing and immunolabeling for $04, G C$, and GFAP (see below). At various time points after reseeding, cultures were fixed for $20 \mathrm{~min}$ in $2 \%$ paraformaldehyde in MEM-HEPES and, following immunocytochemistry, dehydrated and then stored for in situ hybridization. In a few instances, MTT survival assay was performed to detect active mitochondria in living oligodendrocytes as described (Barres et al., 1992).

Triple immunolabeling combined with autoradiography for tritiated thymidine. Two to seven days before fixing, methyl- ${ }^{3} \mathrm{H}$-thymidine $\left({ }^{3} \mathrm{H}\right)$ (45 $\mathrm{Ci} / \mathrm{mm}$; Amersham) was added $(0.1 \mu \mathrm{Ci} / \mathrm{ml}$ culture medium) to the cultures. These cultures were then fixed and triple immunofluorescence labeling combined with autoradiography of ${ }^{3} \mathrm{H}$ was performed as described (Armstrong et al., 1992). All fixation, staining methods, antibodies, and conjugates used here have been described before (Sommer and Schachner, 1981; Ranscht et al., 1982; Bansal et al., 1989; Armstrong et al., 1992). The only change was that the rabbit anti-GFAP was bought from Chemicon (Temecula, CA). With this method, four different cell types can be identified in the same culture: preoligodendrocytes (O4 only), oligodendrocytes (O4 and GC positive), type 2 astrocytes (O4 and GFAP positive), and type 1 astrocytes (GFAP only). For the quantitative analysis of DNA synthesis, cells of each phenotype, with and without ${ }^{3} \mathrm{H}$ labeling in their nuclei, were counted in 20 random optical fields $\left(0.88 \mathrm{~mm}^{2}\right)$ using the 25 fluotar oil-immersion objective on the axiophot Zeiss microscope. In most experiments, duplicate or triplicate cultures in similar conditions were analyzed.

Immunocytochemistry combined with in situ hybridization. The $\mathrm{O} 4$ antigen in the cultures was visualized using a monoclonal antibody and the diaminobenzidine-glucose oxidase method (DAB-GO) (Shu and Fan, 1988). Cultures were treated at room temperature (RT) with O4 antibody diluted 1:4 in phosphate-buffered saline (PBS). The antibody solution was first treated with ribonuclease inhibitor (RNase block II from Stratagene, La Jolla, CA). Next, the cultures were washed with PBS, and incubated with biotin-conjugated goat anti-mouse IgM (Vector, Burlingame, CA) diluted 1:200 in PBS for $1 \mathrm{hr}$; horseradish peroxidase-conjugated avidin biotin complex (Vector) 1:50 in PBS for 45 $\mathrm{min}$, followed by Tris-buffered saline (TBS) for $15 \mathrm{~min}$. Finally, the color reaction was developed with $0.05 \% \mathrm{DAB}$ in TBS, $\mathrm{pH} 7.6$, containing $0.4 \%$ dextrose. $0.04 \%$ ammonium chloride, $0.14 \%$ imidazole, and $0.5 \%$ GO (type VII; Sigma), for $10 \mathrm{~min}$. Cultures were then immediately dehydrated in graded alcohols and stored at room temperature in a dry environment until the in situ hybridization was performed.

For some experiments on tissue sections, in situ hybridization was combined with immunofluorescence for GFAP. After the posthybridization washes, slides were again fixed for $5 \mathrm{~min}$ in $4 \%$ paraformaldehyde, washed in PBS, blocked with 10\% BSA for $30 \mathrm{~min}$, washed again in PBS, and then incubated with anti-GFAP (see above) for $1 \mathrm{hr}$ followed by biotinylated donkey anti-rabbit IgG for $45 \mathrm{~min}$, followed by AMCA for $45 \mathrm{~min}$. Slides were then washed again, dehydrated, and air dried for autoradiography.

In situ hybridization. The fresh-frozen biopsy tissue was sectioned at 10-12 $\mu$ on a cryostat, collected onto slides coated with 3-aminopropyltriethoxysilane (Digene, Beltsville, MD), and stored at $-70^{\circ} \mathrm{C}$. All the solutions were either sterile or treated with diethyl pyrocarbonate (DEPC) to minimize degradation of mRNAs by ribonuclease. Pretreatment of the cultures for in situ hybridization was done following the protocol described by Jordan (1990). Pretreatment of tissue sections and then the in situ hybridization for both tissue sections and cultures was donc according to the methods described before for oligonucleotide probes (Jordan, 1990; Bradley et al., 1992) and for riboprobes (Pringle et al., 1989). The temperature of hybridization was $37^{\circ} \mathrm{C}$ for oligonucleotide probes and $55^{\circ} \mathrm{C}$ for riboprobes.

Probes were prepared to detect the expression of the following genes: PLP, MBP (exon 1 and exon 2 probes), PDGF $\alpha$ R, and MyTI. Two types of probes were prepared.

(1) Oligonucleotide probes (48-mers) were synthesized on a DNA synthesizer (Applied BioSystems) and end-labeled with ${ }^{35} \mathrm{~S}$ dATP (DuPont, Wilmington, DE) using terminal deoxynucleotidyltransferase before being purified with G-50 push columns (Stratagene) followed by phenol-chloroform extraction and ethanol precipitation. The human MBP and PLP antisense oligonucleotide probe sequences were as follows: MBP exon 2 (Kamholz et al., 1986, Fig. 4), 5' CTTGTACAT GTTGCACAGCCCAGGCTGGCTGCGGGCATGAGAGGGCAG 3; MBP exon 1, 37-84 (Kamholz et al., 1986), 5' CAGGTACTTGGATC. CGTGCCTCTGGGAGGGTCTCTTCTGTGACGCCAT 3'; PLP, 79126 (Diehl et al., 1986), 5' TGTGCCAGTGAGGGCTTCATGTCCACAGCCACAGAACAGTGCCACCCC 3'. The corresponding sense probes were synthesized for each of these oligonucleotide probes. None of the antisense probes bound to liver frozen sections.

(2) Riboprobes were used for the detection of less abundant mRNAs such as the PDGF $\alpha$ R and MyTI. A single-stranded ${ }^{35}$ S-labeled RNA probe for the rat PDGF $\alpha \mathrm{R}$ was generated by in vitro transcription from a 1.5 kilobase $(\mathrm{kb}) S a c I-P v u I I$ fragment of the extracellular domain of the receptor cloned into pGEMI (Pringle et al., 1992). This region of rat PDGF $\alpha$ R bears $83.2 \%$ homology with human PDGF $\alpha \mathrm{R}$ (Lee et al., 1990). The MyTI cDNA was cloned into a pT3T7 18U vector (Pharmacia) and linearized separately with $E c o R V$ and $B g l I I$. This MyTI 
Table 1. Quantitative analysis of white matter sections after in situ hybridization for PLP, MBP exon 1, MBP exon 2, MyTI, and PDGF $\alpha$ R

\begin{tabular}{lcl} 
Probe & $\begin{array}{l}\text { No. of specimens } \\
\text { with positive cells }\end{array}$ & $\begin{array}{l}\text { Average no. } \\
\text { of cells/ } \\
\text { field } \pm \text { SD }\end{array}$ \\
\hline PLP & $\begin{array}{l}\text { 18/18 epilepsy } \\
3 / 3 \text { control }\end{array}$ & $30 \pm 6$ \\
MBP exon 1 & $\begin{array}{l}\text { 18/18 epilepsy } \\
\text { 3/3 control }\end{array}$ & $27 \pm 5$ \\
MBP exon 2 & $18 / 18$ epilepsy & $28 \pm 5$ \\
3/3 control & $5 \pm 3$ \\
PDGF $\alpha \mathrm{R}$ & 7/11 epilepsy & $6 \pm 2$ \\
MyTI & $4 / 4$ control & $0.2^{a}$ \\
& $6 / 10$ epilepsy & $0.5^{a}$ \\
3/3 control & $0.3^{a}$
\end{tabular}

A total of 18 temporal biopsies from epileptic patients (ages, 13-5I years) were obtained, all of which were tested with PLP and MBP exon 1 and 2 prubes. Of these biopsies, 10 and 11 were tested for MyTI and PDGF $\alpha$ R, respectively. Controls include three (two in case of MyTI) autopsy specimens from adult brain temporal lobes (ages, 49-61 years) and a child's cerebellar biopsy (age, 5 years). One optical field corresponds to $0.55 \mathrm{~mm}^{2}$, the number of cells binding the individual probes were counted in 10 fields for each biopsy, and the mean number of positive cells (with standard deviation, SD) of all biopsies studied is shown.

"No SD because of the small number of positive cells found.

riboprobe is 749 base pairs (bp) long, corresponds to a cDNA region located downstream from the sixth zinc finger, and includes the 3 untranslated region (Kim and Hudson, 1992). For both of these riboprobes, antisense and sense probes were transcribed and labeled with ${ }^{35} \mathrm{~S}$ in vitro using $\mathrm{T} 3$ and $\mathrm{T} 7$ polymerase, respectively.

To determine the specificity of probe binding, all in situ hybridization experiments on human brain cryostat sections and white matter cultures were run in parallel with antisense and sense oligonucleotide probes or riboprobes. In no case did the sense probe show signal above background. To determine whether any antisense probe would recognize transcripts expressed in astrocytes, in situ hybridization was combined with immunofluorescence staining for GFAP, a specific intermediate filament protein of astrocytes (as described above) in 11 experiments with brain tissue sections. In no case did we find probe binding to coincide with the GFAP staining. Thus, glial cells of the human brain expressing myelin genes and genes specific for developing OL cells are likely to belong to the oligodendrocyte lineage. Similarly, to determine in which cultured glial cells specific probe binding occurred, the majority of human white matter cultures were labeled prior to in situ hybridization with the $\mathrm{O} 4$ antibody, which binds only to cells of the OL lincage. Antisense probe binding was detected only in these $\mathrm{O} 4+$ cells.

Following in situ hybridization, slides and cultures were coated with Kodak NTB2 nuclear track emulsion (diluted $1: 1$, at $42^{\circ} \mathrm{C}$ ), exposed at $4^{\circ} \mathrm{C}$ for up to 4 weeks, developed at $15^{\circ} \mathrm{C}$ in Kodak D19, and fixed with Kodak fixer. The slides were then counterstained with hematoxylin (Sigma) diluted 1:1 in water and mounted on permanent mountant. The slides were examined on a Zeiss microscope under both dark-field and bright-field objectives. Cultures were examined and photographed similarly.

Quantitative analysis of in situ hybridization. For evaluation of the number of positive cells in cryostat sections counterstained with hematoxylin, 10 optical fields (examined with a $40 \times$ objective and measuring $\sim 0.55 \mathrm{~mm}^{2}$ ) were examined for each biopsy and the number of cells with a grain density five times above background was counted before calculating the mean and SD.

In order to evaluate the effects of bFGF on gene expression, a quantitative analysis of the hybridized oligodendrocyte cultures was performed on a Zeiss microscope. An O4-positive cell was scored positive if the grain density on the cell body was at least five times higher than the background. Twenty random fields were counted per dish and all experiments were in duplicates.

\section{Results}

The mvelinated human brain contains glial cells expressing genes characteristic of an early stage of oligodendrocyte development

We first examined the expression of developmentally regulated and myelin genes in the oligodendrocyte in the adult human brain using in situ hybridization. Radioactive probes were applied to cryostat sections of temporal lobe white matter of 18 epileptic patients and four controls, which included a child's cerebellum tissue (see Materials and Methods). We first studied expression of myelin genes using oligonucleotide probes for MBP and PLP (Jordan et al., 1989a; Jordan, 1990). MBP exon 1 probe detects all MBP transcripts that code for the 21.5, 20.2, 18.5, and $14 \mathrm{~K}$ MBPs, while MBP exon 2 probe detects only transcripts coding for the 21.5 and $20.2 \mathrm{~K}$ (Kamholz et al., 1987, 1988; Kamholz and Wrabetz, 1992). Because all sequences specific for the alternativcly spliced MBP RNAs are also present in the larger transcripts (coding for the 21.5 and $20.2 \mathrm{~K} \mathrm{MBP}$ ), the signals for exon 2 must be subtracted from those obtained with the exon 1 probe to appreciate the amount of alternatively spliced short transcripts coding for the 18.5 and $17.2 \mathrm{~K} \mathrm{MBP}$ (Jordan et al., 1989a,b).

In the myelinated human white matter of epileptic patients, we detected a mean of 30 cells per optical field expressing PLP transcripts and of 27 cells per optical field expressing all MBP transcripts detected by the exon 1 probe (Table 1). Immunoperoxidase staining for CNP, a myelin protein detected in the oligodendrocyte cytoplasm (Vogel et al., 1988), revealed $34 \pm$ 6 positively stained oligodendrocytes per field (as defined in Table 1) in cryostat sections of brain tissue of three epileptic patients and one control. It thus appears that the large majority of oligodendrocytes $(\sim 84 \%)$ contain transcripts for the major myclin genes, as expected. Glial cells expressing MBP exon 2containing transcripts were five to six times less frequent than those expressing PLP in the human white matter (Table 1, Fig. $1 A, C)$.

The temporal white matter of the three controls and the child cerebellar white matter folia contained a similar ratio of MBP exon $2+$ cells to PLP + cells (Table 1 , Fig. $1 F-H$ ). No MBP exon 2 signal was found to be associated with astrocytcs positive for glial fibrillary acidic protein (GFAP) in experiments on 11 biopsies (Fig. $1 B$ ). Therefore, MBP exon $2+$ cells are most likely to belong to the oligodendrocyte lineage. [It is not known whether glial cells in the human white matter express the Golli gene transcripts coded by a newly described transcription unit encompassing the MBP gene or at least exon 1 (Campagnoni et al., 1993; Pribyl et al., 1993).] When gray matter sections from three epileptic patients were hybridized with the same three probes used on white matter sections, many fewer cells expressing either PLP or MBP transcripts were found in the cortex (PLP, 9 cells per optical field, \pm 2 SD; MBP exon 1, $7 \pm 2$ SD; MBP exon 2, $2 \pm 1 \mathrm{SD}$ ). These cells were frequently seen close to neurons and may correspond to satellite oligodendrocytes. The ratio of cortical cells expressing MBP exon 2 transcripts to those expressing all MBP transcripts or PLP was similar to that observed in white matter $(<20 \%)$.

We then examined the expression of PDGF $\alpha \mathrm{R}$ and MyTI transcripts in cortex and myelinated white matter using riborobes. Cells expressing these transcripts were very rare compared to those expressing PLP (Table 1, Fig. $1 D, E$ ). In control $\mathrm{CNS}$ tissue, the number of cells expressing PDGF $\alpha$ R (four cases) 

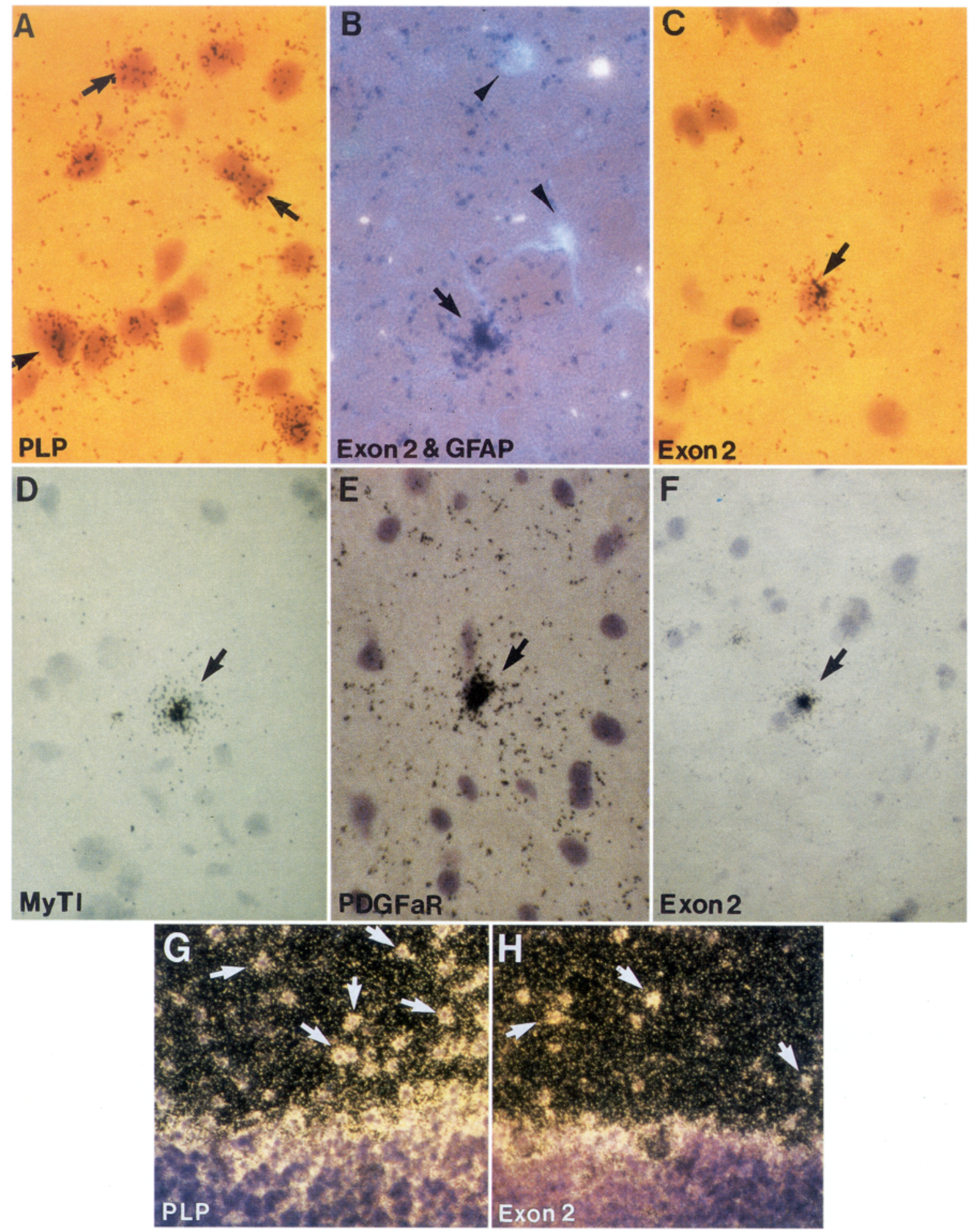

Figure 1. In situ hybridization on human CNS sections using ${ }^{35}$ S-labeled oligoprobes for PLP $(A, G)$ and MBP exon $2(B, C, F, H)$ as well as riboprobes for MyTI $(D)$ and $\mathrm{PDGF} \alpha \mathrm{R}(E)$. Sections are counterstained with hematoxylin except for $B$, which was stained by immunofluorescence for GFAP following in situ hybridization with MBP exon 2 probe. $A-E$, In adult white matter from epileptic patients, numerous cells-probably oligodendrocytes - express PLP (arrows in A), while a smaller number of cells express MBP exon 2 transcripts with variable intensity (arrows in $B, C$ ). Only rare cells express MyTI or PDGF $\alpha$ R mRAs (arrows in $D, E$ ). The MBP exon 2-labeled cells do not stain with GFAP antibody detected by the blue coumarin conjugate and are likely to belong to the oligodendrocyte lineage ( $B$; GFAP-positive blue astrocytes are seen at the arrowheads). $F$. Adult control white matter obtained at autopsy shows MBP exon 2-positive cells (arrow) as shown in $B$. $G$ and $H$, Cerebellar tissue from a 5-year-old child shows PLP signal in all oligodendrocytes in the white matter, while only a subpopulation of cells express MBP exon 2 (arrows). Note that the granular layer is at the bottom of each micrograph. All photographs are in bright field except for $B, G$, and $H$. $B$ is a double exposure in bright field and UV light, while $G$ and $H$ are dark-field photographs. Magnification: $A-C, 747 \times ; D-F, 500 \times ; G$ and $H, 312 \times$. 

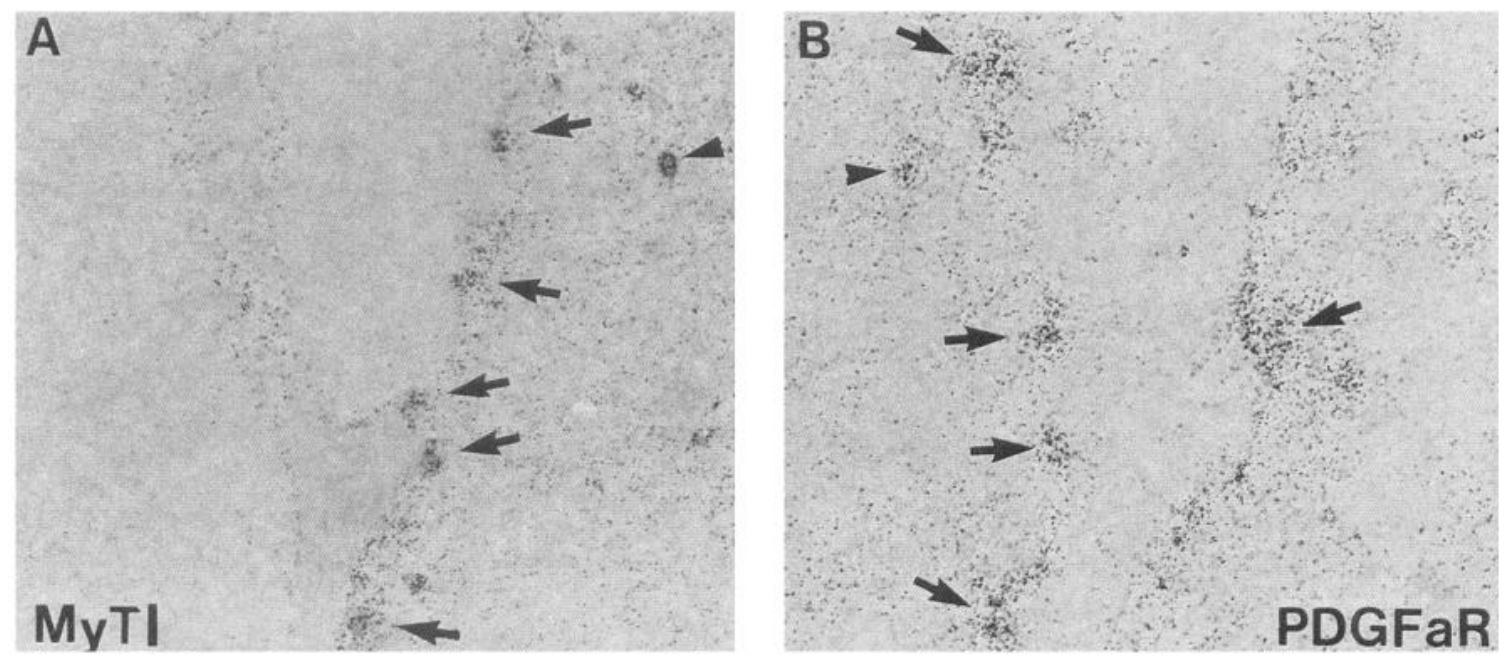

Figure 2. Adjacent sections of the periventricular region of the temporal lobe from an adult epileptic brain were hybridized with MyTI $(A)$ and PDGF $\alpha \mathrm{R}(B)$ probes. The subependymal zone shows groups of MyTI- and PDGF $\alpha \mathrm{R}$-expressing cells (arrows in $A$ and $B$, respectively). One PDGF $\alpha$ R-positive cell and one MyTI-positive cell appear at some distance from the zone (arrowheads). Sense riboprobes did not produce signal over background. Bright-field photographs. Magnification, $206 \times$.

or MyTI (three cases) transcripts was approximately double that seen in epileptic tissue. However, this may not be a significant observation because of the small series of controls examined and the rarity of these positive cells. The frequency of cells expressing PDGF $\alpha$ R and MyTI was identical in cortex and white matter and $\sim 12-25$ times less than that of cells expressing MBP exon 2-containing transcripts (Table 1). In both controls and epileptic brains, the grain density observed with PDGF $\alpha \mathrm{R}$ and MyTI probes varied from cell to cell, suggesting different levels of expression in individual cells. Thus the human myelinated white matter contains a discrete population of cells expressing $\mathrm{PDGF} \alpha \mathrm{R}$ and/or MyTI, two genes developmentally regulated in rat $\mathrm{O}-2 \mathrm{~A}$ progenitors.

In one case of partial temporal lobectomy for epilepsy in a 19-year-old patient, a small area of the periventricular region was identified and hybridized with MyTI and PDGF $\alpha$ R probes. Adjacent sections revealed a row of cells in the subventricular zone containing these transcripts and localized beneath the ependyma (Fig. 2A,B). One cell expressing these transcripts was found in the brain parenchyma at some distance from the ependyma (arrowheads in Fig. 2). As the adult subventricular zone can harbor glial precursors, these observations also suggest that PDGF $\alpha$ R- and/or MyTI-expressing cells are preoligodendrocytes.

\section{Developmentally regulated genes are also expressed in the human oligodendrocyte lineage in vitro}

When the myelinated human white matter is dissociated for culturing, the majority of oligodendrocytes are sheared from their multiple myelin internodes, which are extensions of their processes. Only the rare OL cells that do not have membranes wrapped around axons (preoligodendrocytes) may be less sheared in the tissue dissociation step and appear to adhere more readily in primary cultures (see Fig. $4 G$ ). In cultures enriched in OL cells, cells attach to the positively charged plastic surface and slowly grow processes (Armstrong et al., 1992). To determine whether human OL cells regenerating in vitro also express genes characteristic of an early developmental stage, we performed in situ hybridization on OL-enriched cultures at 7, 14, or $21 \mathrm{~d}$ with the same probes used on the intact human brain (Fig. 3; see also Fig. 6). In several experiments, OL cells were immunolabeled with the $\mathrm{O} 4$ antibody prior to in situ hybridization (Fig. 3A-C,E; see also Fig. $6 B-F$ ). Type 2 astrocytes are rare in cultures enriched in OL cells (see Fig. 2 in Armstrong et al., 1992), although they can occasionally divide (see below). Thus, the majority of $\mathrm{O} 4+$ cells are preoligodendrocytes and/or oligodendrocytes and will therefore be called "OL cells."

In contrast with our in vivo observations, only a small fraction of OL cells (9-17\% vs $84 \%$ in vivo) contained MBP transcripts (detected by exon 1 probe) at $7 \mathrm{~d}$ in vitro and this ratio varied from biopsy to biopsy (see also Fig. 7A). The ratio of OL cells expressing MBP exon 2 transcripts was always slightly lower than that of OL cells binding the MBP exon 1 probe and varied from $5 \%$ to $14 \%$ at $7 \mathrm{~d}$ (see Fig. $7 . A$ ). This suggests that the majority of OL cells binding the MBP probes in vitro contain exon 2 MBP transcripts while only $15-20 \%$ of the total oligodendrocyte population in the intact white matter expresses these same transcripts (Table 1). As seen with MBP, only a fraction of OL cells expressed PLP transcripts at $7 \mathrm{~d}$ in vitro (Fig. $3 \mathrm{~A}$; $22 \%$ ), whereas the great majority of cells identified as oligodendrocytes expressed PLP in the intact white matter (Table 1). In contrast, the great majority of OL cells (a mean of $81 \%$ in two biopsies; Fig. 3C) expressed transcripts for PDGF $\alpha$ R at $7 \mathrm{~d}$ (see Fig. 7C). Similarly, a higher but variable proportion of OL cells ( $10 \%$ of OL cells in one biopsy and $29 \%$ in another) expressed MyTI in vitro than in the intact brain (Table 1, Fig. 1). All these transcripts were detected only in OL cells and were localized mostly in the cell body and not in the processes (Fig. $3 A, C$; see also Fig. $6 D, F)$.

At $14 \mathrm{~d}$ in vitro, the proportion of OL cells expressing PLP and MBP transcripts had increased considerably while the initial high ratio of PDGF $\alpha$ R-expressing cells remained constant (see Fig. 7B,C). At 3 weeks, most oligodendrocytes with a complex branched phenotype expressed PLP and mature MBP messages when cultured in the presence of high insulin levels (Fig. 3D,E). At that time PLP mRNAs were still restricted to the cell soma (Fig. $3 D$ ), while MBP mRNAs, detected by exon 1 probe, were also present in the processes (Fig. $3 E$ ), as observed in mature rodent oligodendrocytes (Trapp et al., 1987; Jordan et al., 1989a).

Although it is not possible to rigorously compare the in vitro 

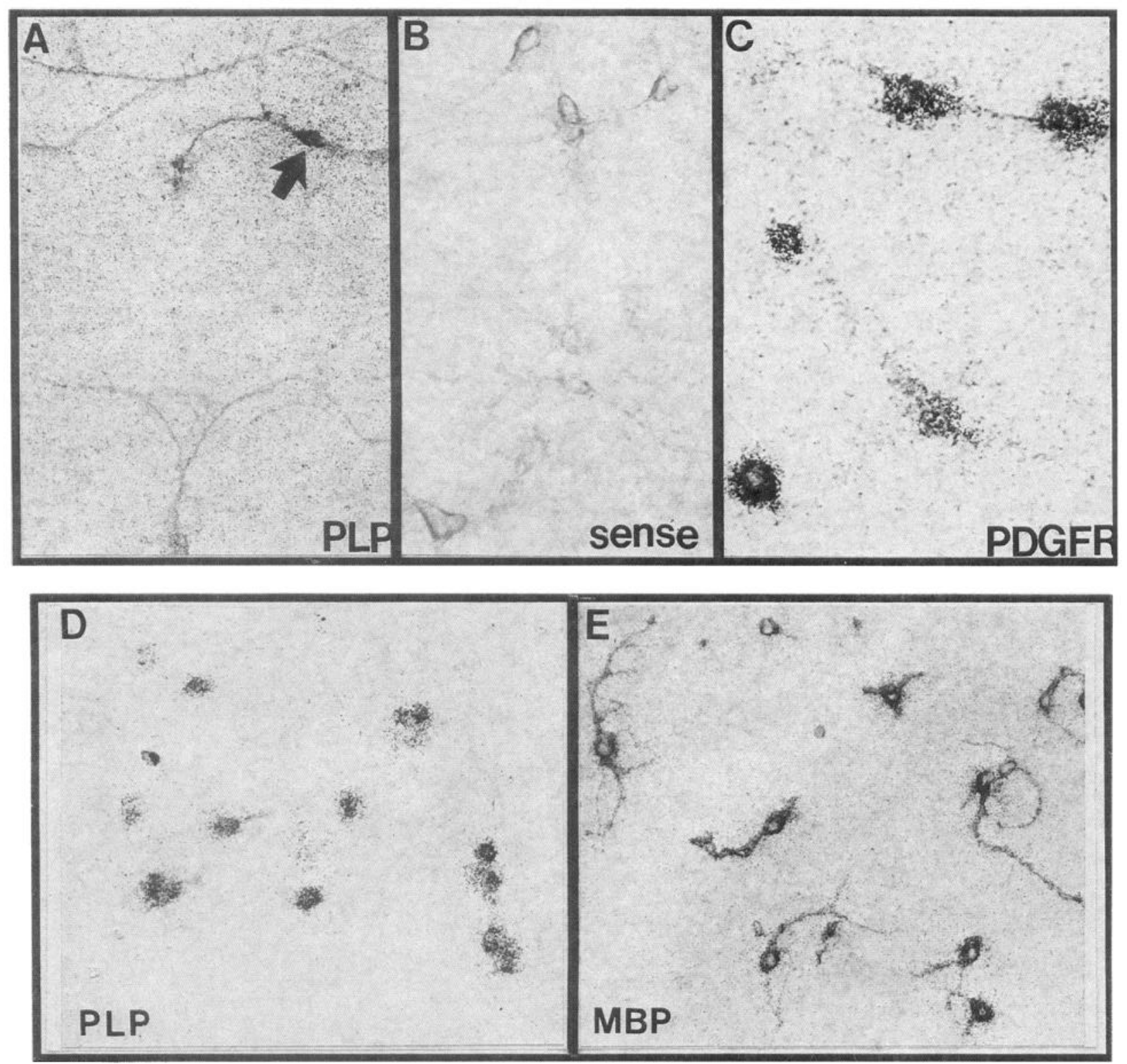

Figure 3. Localization of transcripts for PDGF $\alpha$ R and the major myelin genes, MBP and PLP, in cells of the oligodendrocyte lineage (OL) at different times in vitro. All cultures were stained by immunoperoxidase with the $\mathrm{O} 4$ antibody prior to in situ hybridization except those in $D$. After $7 \mathrm{~d}$ in culture, only a fraction of processed O4+ cells contain PLP transcripts $(A)$, while most cells bind the PDGF $\alpha \mathrm{R}$ antisense probe $(C)$. O4labeled cells exposed to a PDGF $\alpha \mathrm{R}$ sense probe stay unlabeled $(B)$. After 3 weeks in culture in medium containing high insulin levels $(5 \mu \mathrm{g} / \mathrm{ml})$, most oligodendrocytes express PLP $(D)$ and mature MBP transcripts as detected by MBP exon 1 probe $(E)$. Note that PLP and PDGF $\alpha$ R are restricted to the cell soma $(A, C, D)$, while MBP transcripts are present in the cell processes $(E)$. Bright-field photographs. Magnification: $A, D, E$, $206 \times: B$ and $C, 540 \times$.

and in vivo ratio of cells expressing specific transcripts, the emerging picture is that many more OL cells express developmentally regulated genes in vitro than in vivo. With time in vitro, most cultured OL cells will express myelin gene transcripts characteristic of mature oligodendrocytes. To study the process of regeneration further, we then investigated how certain growth factors influence the regeneration and gene expression by $\mathrm{OL}$ cells in vitro.

\section{bFGF and/or PDGF do not induce mitosis of human} preoligodendrocytes and oligodendrocytes in primary and enriched $O L$ cultures

In the presence of bFGF alone, glial cell types other than oligodendrocytes and preoligodendrocytes underwent DNA syn- thesis in enriched oligodendrocyte cultures as assayed by a $2-$ $6 \mathrm{~d}$ pulse with tritiated thymidine (Fig. $4 A, B$ ). Type 2 astrocytes, which are the rarest cells of the $\mathrm{O}-2 \mathrm{~A}$ lineage encountered in these cultures, were found to sometimes incorporate tritiated thymidine with or without bFGF treatment (Fig. $4 A, E, F$ ). Moreover, $b F G F$ always produced a significant increase in the number of type 1 astrocytes in DNA synthesis as compared to untreated cultures (Fig. 4B).

PDGF and bFGF can stimulate mitosis of $\mathrm{O}-2 \mathrm{~A}$ neonatal progenitors and induce a reversal from the adult $\mathrm{O}-2 \mathrm{~A}$ progenitor to the neonatal O-2A phenotype in adult rat optic nerve cultures (Bogler et al., 1990; Wolswijk and Noble, 1992). To determine whether human preoligodendrocytes respond to these factors in a similar manner, cultures enriched in human OL cells 
A
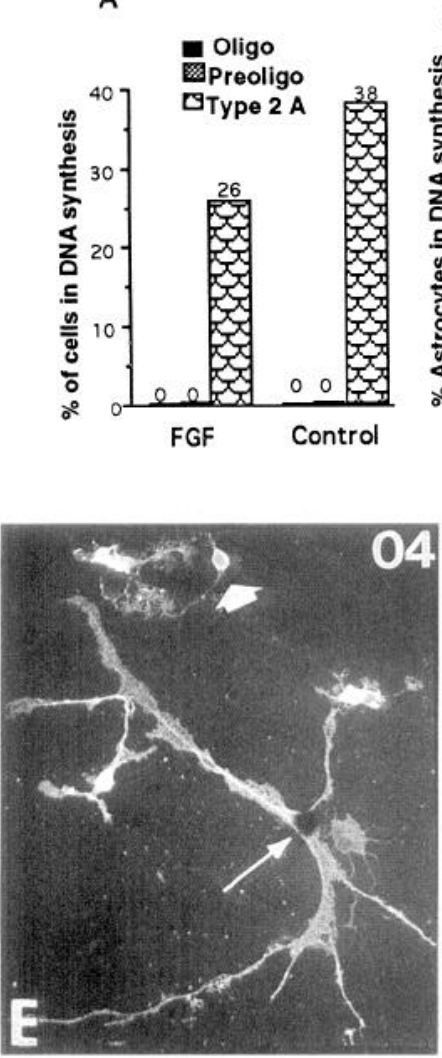

B

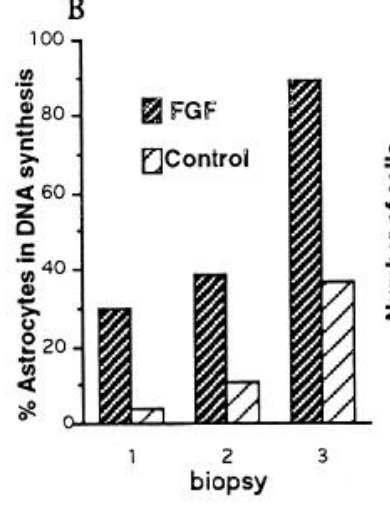

C

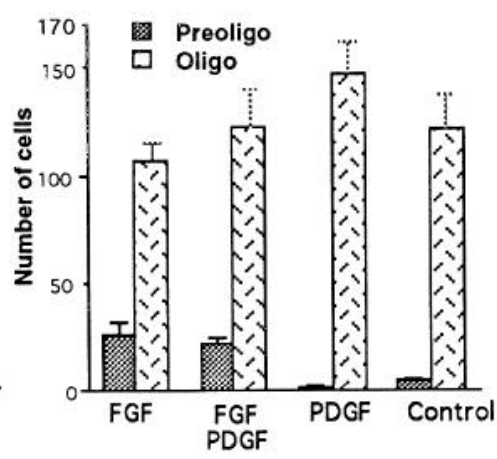

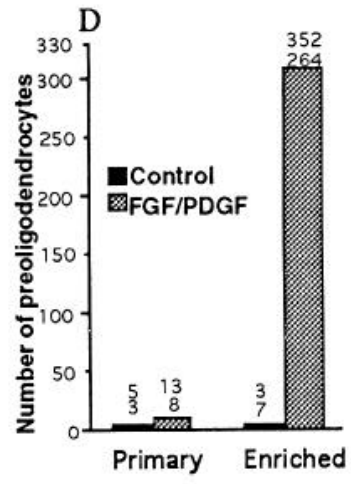
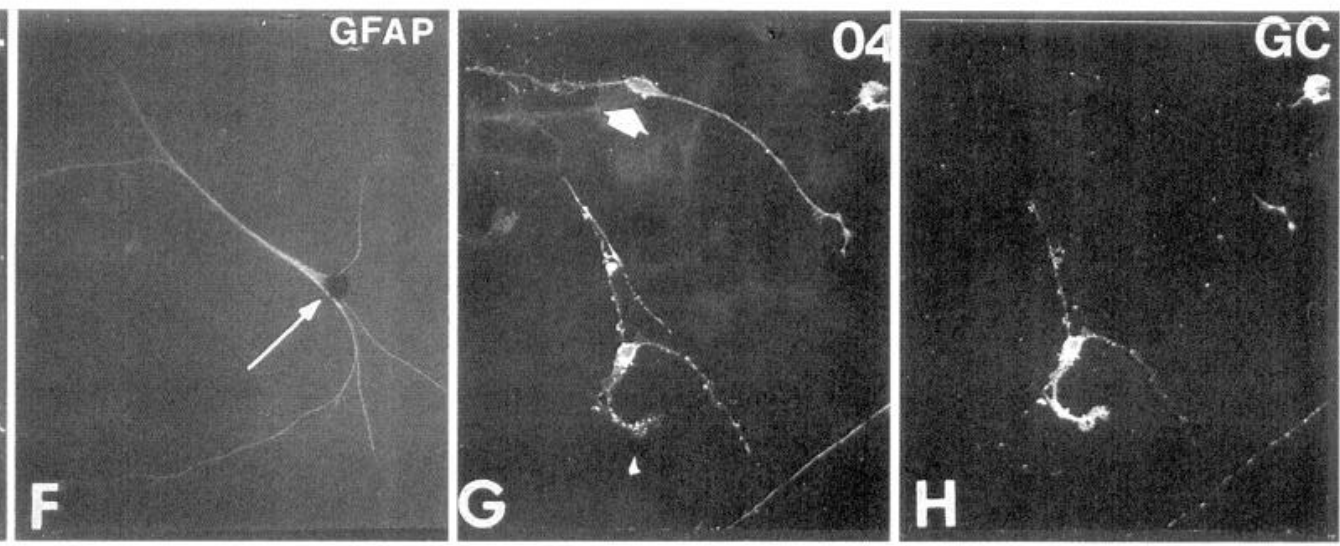

Figure 4. Absence of mitogenic effect of bFGF and PDGF in OL cells in primary $(D, G, H)$ and enrrched cultures $(A-F)$. In all the experiments shown here the cells were labeled with tritiated thymidine before being fixed and triple labeled for O4/GC and GFAP to analyze antigenic phenotypes and cells in mitosis. Data on DNA synthesis are shown in $A, B$, and $E-H$, but not in $C$ and $D . A$, At 4 d, no preoligodendrocytes and oligodendrocytes were found in DNA synthesis after a $2 \mathrm{~d}$ pulse with tritiated thymidine in contrast to type 2 astrocytes, which can divide independent of bFGF treatment. The numbers are percentage of cells in DNA synthesis in one representative dish of biopsy 4 . $B$, bFGF significantly enhances DNA synthesis in human type 1 astrocytes. The tritiated thymidine pulse lasted $3 \mathrm{~d}$ in biopsies 1 and 2 and $6 \mathrm{~d}$ in biopsy 3 cultures. The percentage of human type 1 astrocytes dividing in the presence of bFGF is 2.5-6 times that seen in control. $C$, bFGF, with or without PDGF, but not PDGF alone, maintains a significant number of preoligodendrocytes in low-density cultures after $10 \mathrm{~d}$. After such time in vitro, the majority of the regenerating cells are GC-expressing oligodendrocytes in all growth factor conditions and in the presence of $50 \mathrm{ng} / \mathrm{ml}$ of insulin. (None of the preoligodendrocytes or oligodendrocytes were thymidine labeled after a $3 \mathrm{~d}$ pulse; not shown.) Triplicate cultures were analyzed and error bars represent the SD. D. PDGF and bFGF together with tritiated thymidine were added at the time of white matter dissociation as well as after reseeding for a total of $7 \mathrm{~d}$. (Only one GC/O4 cell was found to incorporate thymidine in the primary cultures; not shown.) In the enriched cultures, this early factor treatment results in a 50 -fold increase of preoligodendrocytes over control, although none of these cells were thymidine labeled (not shown). The bars represent the mean of cell counts in two dishes and the raw numbers are indicated above the bars. $E$ and $F, \mathrm{O} 4+(E) / \mathrm{GFAP}+$ $(F)$ type 2 astrocyte in DNA synthesis (long arrow) is seen $5 \mathrm{~d}$ after reseeding and constant pulsing with tritiated thymidine in control medium without bFGF. Short arrow indicates $\mathrm{O} 4+$ cell with no thymidine incorporation. $G$ and $H$, At $2 \mathrm{~d}$ in primary cultures treated with PDGF and bFGF. scattered preoligodendrocytes (O4+ only, short arrow) and oligodendrocytes $(\mathrm{O} 4+/ \mathrm{GC}+$ in center) sometimes have long processes, but one $\mathrm{GC}+$ oligodendrocyte in the right upper corner does not have any. There is no thymidine incorporation after a $2 \mathrm{~d}$ pulse. Triple immunolabeling O4, GC, GFAP. (The GFAP stain is not shown as it was negative on these cells.) Magnification $(E-H), 206 \times$.

Figure 5. bFGF stimulates growth of processes in enriched and purified cultures of human OL cells. $A-D$, Purified cultures of OL cells were maintained in control medium or treated with $10 \mathrm{ng} / \mathrm{ml} \mathrm{bFGF} 1 \mathrm{~d}$ after reseeding and fixed $7 \mathrm{~d}$ later before staining by triple immunofluorescence for O4/GC/GFAP. In the absence of bFGF, most cells are round or with short processes and express both O4 and GC ( $A, B)$. Short white arrow points to one of the rare cells in the field that expresses O4 and little GC. In the presence of bFGF, most O4+ cells have grown long processes (C). Some of these cells are preoligodendrocytes (O4+ only, long white arrows) while others have one or more GC patches, but only on the cell body (D. short white arrows). Short black arrow points to a rare cell having bright GC staining all over the cell body while its processes are O4 only $(C)$. No GFAP astrocytes were detected in these fields (not shown). Magnification, $206 \times . E$ shows the proportion of round cells and processed cells counted in dishes of cultures enriched in OL cells and stained by triple immunofluorescence. The bars show the mean of cell counts in two dishes with the raw numbers indicated above the bars (there was only one control dish in biopsy 5 ). Cultures treated with $5 \mathrm{ng} / \mathrm{ml}$ of bFGF (in medium with $50 \mathrm{ng} / \mathrm{ml}$ insulin for $4 \mathrm{~d}$ ) showed over a threefold decrease in the number of round cells compared to the controls. Note that there is no significant difference in the number of total cells in each condition. A $2 \mathrm{~d}$ (biopsy 4) and $3 \mathrm{~d}$ (biopsy 5) pulse with tritiated thymidine was done before fixing the cultures and revealed no DNA synthesis in preoligodendrocytes and oligodendrocytes (see Fig. $4 A$ on biopsy 4 ). $F$. Cultures of purified OL cells stained as shown in $A-D$ were analyzed as in $E$ but after $7 \mathrm{~d}$ of bFGF treatment at $10 \mathrm{ng} / \mathrm{ml}$. As with cultures enriched in OL cells, a similar decrease in round cells, increase in processed cells, and absence of DNA synthesis after a $2 \mathrm{~d}$ pulse with tritiated thymidine were observed. 

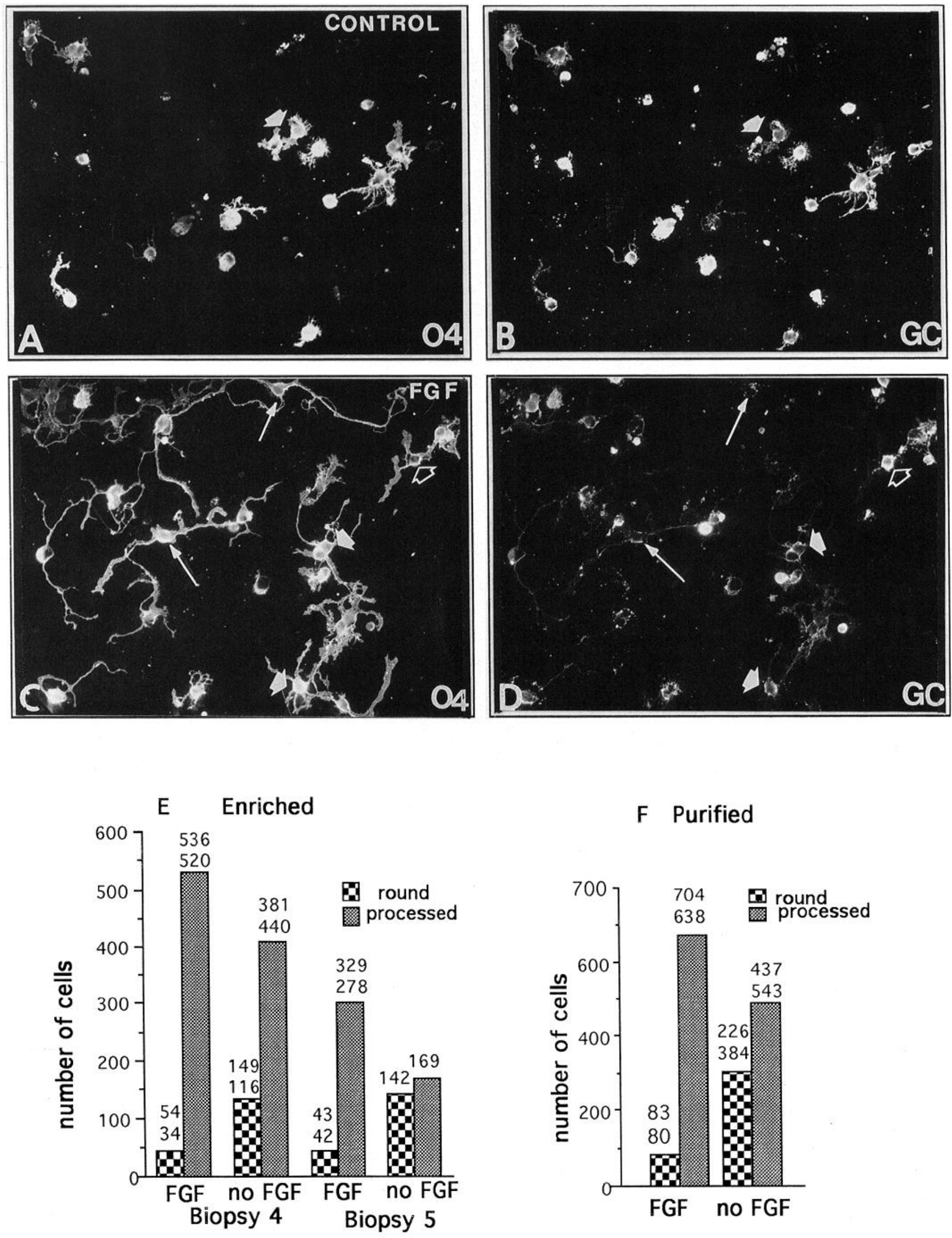

\section{F Purified}

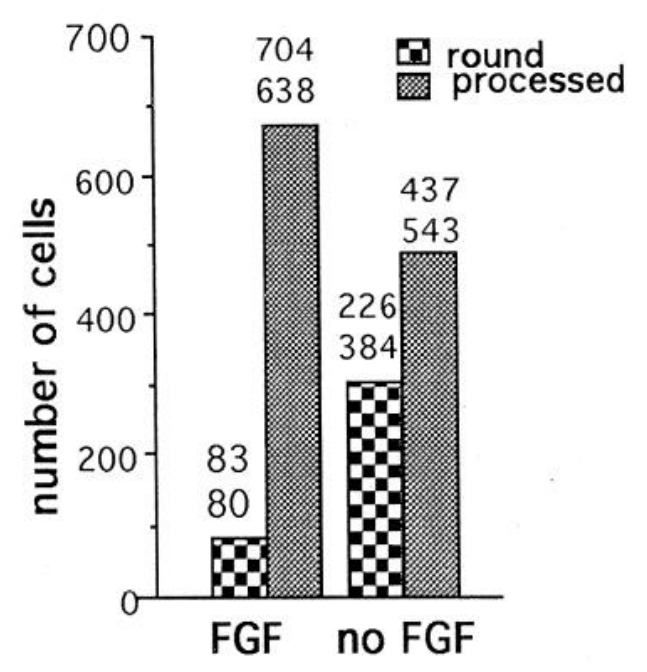



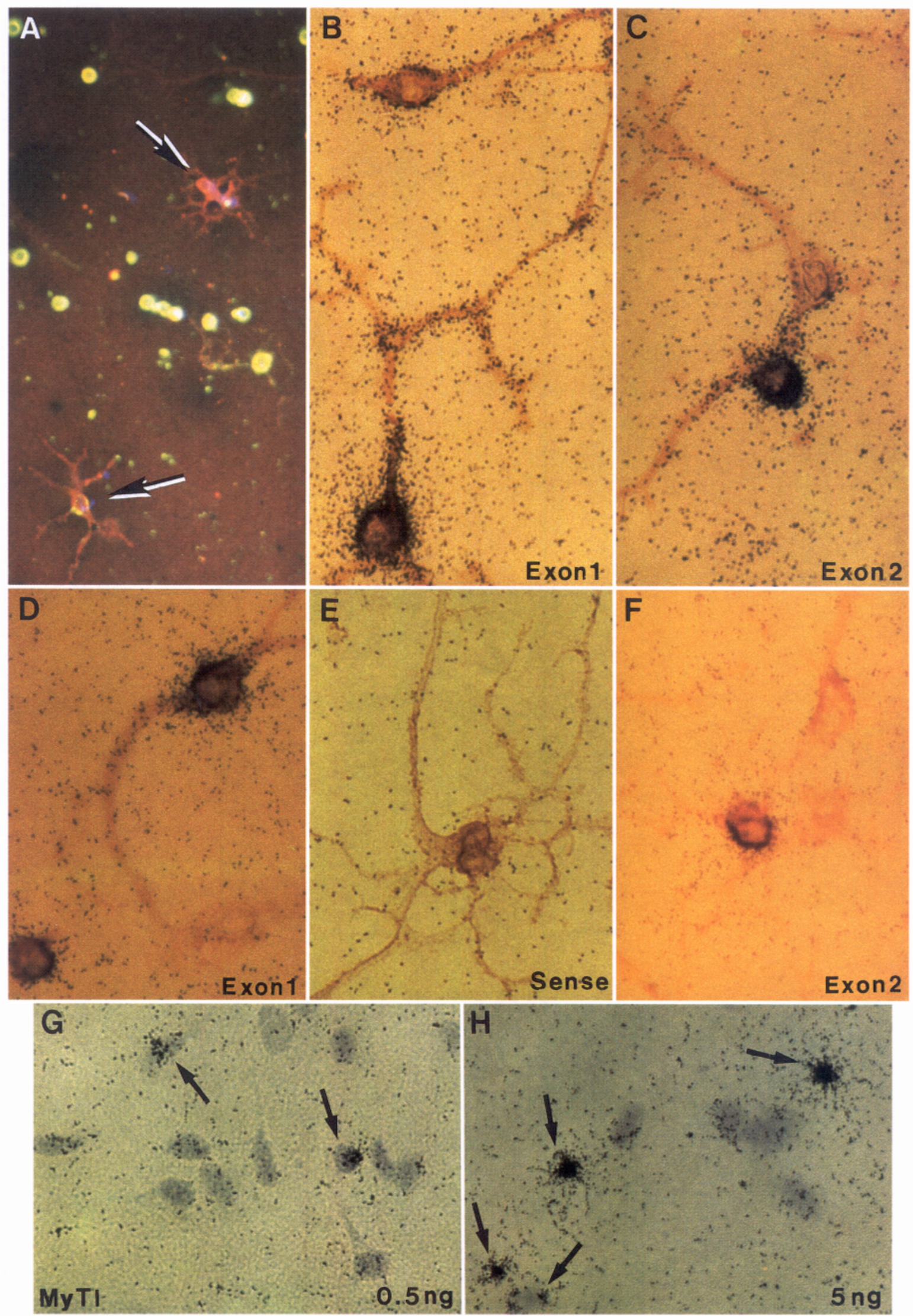

Figure 6. bFGF enhanced regeneration and expression of developmentally regulated genes in cultured human OL cells. $A$ shows early growth of processes in the presence of $5 \mathrm{ng} / \mathrm{ml}$ of bFGF by cells expressing O4 antigen only (upper arrow, red) or O4/GC (lower arrow, red and green). There are several round cells labeled with GC in green and devoid of processes. Triple immunofluorescence for O4/GC/GFAP and triple exposure (see Materials and Methods). Magnification, $312 \times . B-F$, Expression of MBP transcripts is shown in O4+OL cells grown with $5 \mathrm{ng} / \mathrm{ml}$ of bFGF ( $B$, 
were treated with PDGF and bFGF in the presence of low levels of insulin $(50 \mathrm{ng} / \mathrm{ml})$ to avoid IGF-I receptor signaling and at low-density seeding to minimize the influences of growth factors derived from other cell types (Fig. $4 C$ ). In such conditions, the majority of the cells became GC+ oligodendrocytes after $10 \mathrm{~d}$ in vitro. However, a substantial proportion of preoligodendrocytes persisted in cultures treated with $\mathrm{bFGF/PDGF}$ or $\mathrm{bFGF}$ alone, confirming the observation that bFGF favors the development of preoligodendrocytes in vitro (Armstrong et al., 1992). However, neither preoligodendrocytes nor oligodendrocytes incorporated tritiated thymidine during a $3 \mathrm{~d}$ pulse in these experiments. A slightly higher (although not significant) number of total OL cells was observed in growth conditions with PDGF (Fig. $4 C$ ), suggesting a slight enhancement of cell survival by this factor as described in the newborn rat optic nerve (Barres et al., 1992).

Primary cultures contain rare oligodendrocytes, preoligodendrocytes, and type 2 astrocytes bearing processes (Fig. 4G,H). Such processes were probably not sheared during white matter dissociation or grew in response to signals from other cell types. To investigate whether preoligodendrocytes and/or oligodendrocytes can divide during the first $2 \mathrm{~d}$ in vitro, PDGF and bFGF were added at the start of the primary culture right after dissociation and refed to the reseeded cultures from 2 to $7 \mathrm{~d}$ in the constant presence of tritiated thymidine. Such treatment caused a slight increase in the relative number of preoligodendrocytes over controls in primary cultures at $2 \mathrm{~d}$ (Fig. $4 D$ ), but DNA synthesis was observed (Fig. $4 G, H$ ) in only one oligodendrocyte of four cultures examined. This growth factor treatment appears to prime the nonadherent $\mathrm{OL}$ cells to regrow processes promptly (see below) and acquire the preoligodendrocyte phenotype after reseeding. There was indeed a $\sim 50$-fold increase in preoligodendrocytes over controls $5 \mathrm{~d}$ after reseeding (Fig. $4 D$ ). No DNA synthesis was observed in these OL cells pulsed for $7 \mathrm{~d}$.

\section{bFGF enhances regeneration of processes by human $O L$ cells and the development of preoligodendrocytes in vitro}

Yong and Antel (1992) described how, at $24 \mathrm{hr}, 70-80 \%$ of the cells floating in primary cultures are oligodendrocytes. In our primary cultures examined at $2 \mathrm{~d}$, rare oligodendrocytes were detected and expressed GC even when they had not grown processes (Fig. $4 H$ ). Similarly, in enriched OL cultures from 4 to $7 \mathrm{~d}$, most OL cells initially maintained a round shape and expressed both $\mathrm{O} 4$ antigens and $\mathrm{GC}$ on their surface, suggesting that the majority of cultured cells are oligodendrocytes stripped of their myelin sheath (Figs. $5 A, B ; 6 A$ ). A few cells slowly grew processes in the first week and these expressed both $\mathrm{O} 4$ and $\mathrm{GC}$ (Figs. $5 A, B ; 6 A$ ). The addition of $5-10 \mathrm{ng} / \mathrm{ml}$ of bFGF dra- matically accelerated the regeneration of processes bearing $\mathrm{O} 4$ antigens but not GC on their surface (Fig. $5 C, D$ ). The early stage of such bFGF effects is illustrated in Figure $6 A$, where the majority of the cells are still round and expressing GC (in green) while two cells with processes in the field are almost entirely $\mathrm{O} 4+$ (Fig. 6A, arrows). Progressively, however, most OL cells acquired $\mathrm{O} 4+$ processes (Fig. $5 A, C$ ) and lost GC immunoreactivity on the cell body (compare Fig. 5, $B$ and $D$ ), leaving only occasional GC patches (Figs. $5 C, D ; 6 A$ ). Thus, these regenerating OL cells have characteristics of preoligodendrocytes. The bFGF effect was quantitated by comparing the number of $\mathrm{O} 4+$ round cells showing no growth of processes to the number of $\mathrm{O} 4+$ cells with processes. At $4 \mathrm{~d}$, bFGF-treated enriched OL cultures showed a three- to fourfold decrease in the number of round cells and a corresponding increase in processed cells as compared to controls (Fig. $5 E$ ). However, the total number of $\mathrm{O} 4+$ OL cells (round and with processes) was not significantly different after bFGF treatment as compared to controls, indicating that $b F G F$ is not acting as a survival factor at this stage (Fig. $5 E$ ). MTT assays confirmed that viability of both round and processed cells was not significantly enhanced by bFGF (data not shown). bFGF is likely to act directly on OL cells, as cultures of purified OL cells obtained after a Percoll gradient and containing only $0.1-0.2 \%$ astrocytes showed the same induction of process growth in response to bFGF (Fig. $5 C, D, F$ ). The effect of bFGF on process growth at $4 \mathrm{~d}$ was not influenced by the levels of insulin (data not shown).

As described before (Armstrong et al., 1992), bFGF increased the relative number of preoligodendrocytes $(\mathrm{O} 4+, \mathrm{GC}-$ cells) without increasing the total number of OL cells. In the series of human white matter cultures studied here, we regularly found eight to 10 times more preoligodendrocytes in bFGF-treated cultures than in control (Fig. $4 C$ ). We then investigated whether bFGF enhances the expression of developmentally regulated genes in $\mathrm{O} 4+$ cells.

\section{bFGF enhances gene expression in cells of the human oligodendrocyte lineage}

In cultures treated with bFGF for $7 \mathrm{~d}$, MBP exon 1 probe detected abundant transcripts in both soma and processes of OL cells (Fig. 6B). (As mentioned above, the double immunoperoxidase/in situ hybridization method does not allow discrimination between preoligodendrocytes and oligodendrocytes as both types of cells bind the $\mathrm{O} 4$ antibody.) In contrast, total MBP transcripts were located mostly in the cell body of OL cells in control cultures at that time (Fig. 6D). MBP exon 2 probe also detected transcripts restricted to the OL cell body with less intense signal in the absence of bFGF (Fig. $6 F$ ). The number of OL cells with processes containing exon $2+$ and total MBP

\footnotetext{
$C, E)$ or without bFGF $(D, F)$ for $7 \mathrm{~d}$. Immunoperoxidase labeling of $\mathrm{O} 4$ antigens (brown) was performed before in situ hybridization for MBP exon 1 or MBP exon 2 (black silver grains). In bFGF-treated cultures at $7 \mathrm{~d}(B, C)$, there were abundant transcripts detected with both MBP exon $1(B)$ and MBP exon $2(C)$ probes in OL cells. Mature MBP transcripts were detected along the cell processes $(B)$ while MBP exon 2 transcripts were mostly restricted to the cell soma $(C)$. In contrast, in control cultures $(D, F)$ exon 2 transcripts appear less abundant in round cells $(F)$ and even mature transcripts are mostly localized in the cell body $(D)$. When bFGF-treated cultures were hybridized with sense probes $(E$; MBP exon $2), \mathrm{O} 4+$ cells showed only background signal. Bright field. Magnification, $747 \times . G$ and $H$, MyTI expression is stimulated by bFGF treatment in a dose-dependent manner at $7 \mathrm{~d}$. Cells were not immunolabeled with $\mathrm{O} 4$ antibody in this case but counterstained with hematoxylin to show the nuclei. Both the frequency of cells with MyTI transcripts as well as the intensity of grains/cell were higher when cells were treated with bFGF 5 $\mathrm{ng} / \mathrm{ml}(H)$ as compared to $0.5 \mathrm{ng} / \mathrm{ml}(G)$. [The number of MyTI-positive cells seen in control medium (not shown) was similar to that shown in $G$.] The transcripts appear localized only in the cell body, although processes in $G$ are not distinct in the absence of O4 labeling. Bright-field photographs. Magnification, $747 \times$.
} 
A

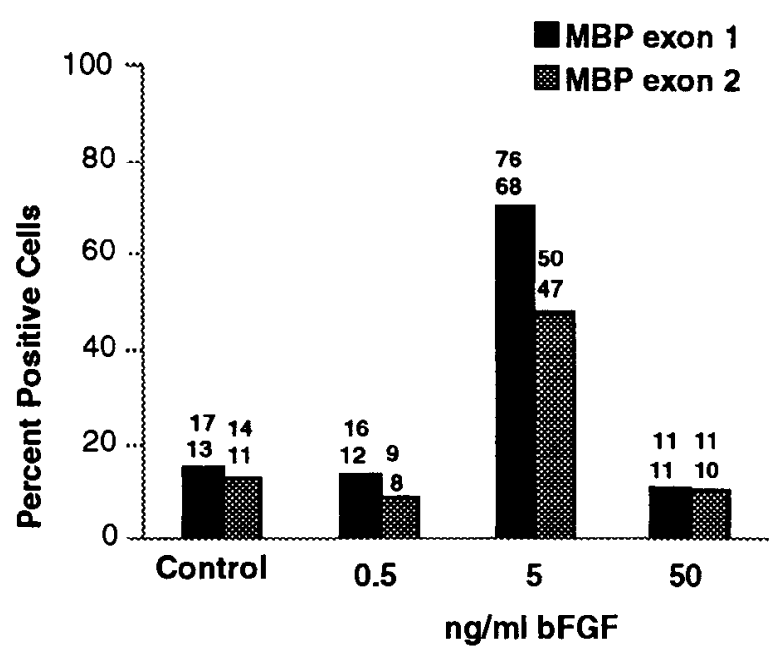

B

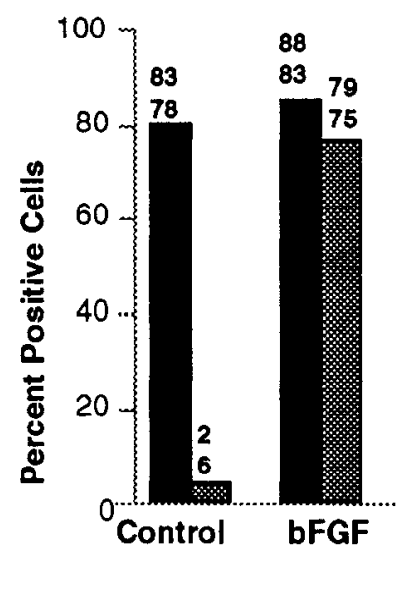

C

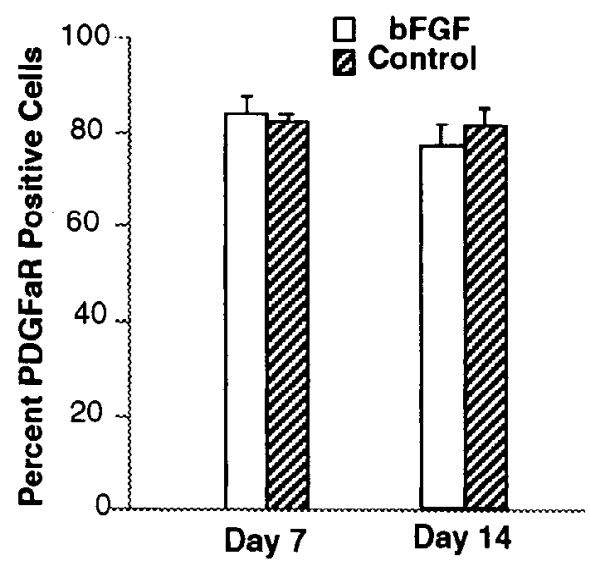

Figure 7. Quantitative analysis of the effects of bFGF on gene expression in cultures enriched in OL cells at 7 and $14 \mathrm{~d}$. $A$, At $7 \mathrm{~d}$, the ratio of OL cells expressing MBP transcripts is strongly increased by bFGF and is dose dependent with a peak in exon 1- and exon 2-positive cells at 5 $\mathrm{ng} / \mathrm{ml}$. Note that the ratio of cells with exon 2 MBP transcripts is always slightly lower than that of cells binding the MBP exon 1 probe. Cultures were fed with medium containing $50 \mathrm{ng} / \mathrm{ml}$ insulin and increasing doses of bFGF before fixation and hybridization at $7 \mathrm{~d}$. Bars represent mean of two dishes from one biopsy for each dose with raw numbers shown above the bars. $B$, At $14 \mathrm{~d}$, a large majority of OL cells express MBP transcripts in both control and bFGF-treated cultures. Yet, in control, the MBP exon 2-containing transcripts have almost disappeared while they persist in over three-fourths of the cells after this long bFGF treatment. Cultures were fed with medium containing $5 \mathrm{micrograms} / \mathrm{ml}$ of insulin and $10 \mathrm{ng}$ of bFGF for 2 weeks before fixing, O4 immunolabeling, and hybridization. Bars represent mean of two dishes from one biopsy with raw numbers shown above the bars. $C$, After 7 and $14 \mathrm{~d}$ in culture, the majority of OL cells contained PDGF $\alpha$ R transcripts regardless of the presence of bFGF. Data are from duplicate cultures from two different biopsies, with SD.

transcripts was then counted in cultures treated or untreated with bFGF (Fig. 7A). After $7 \mathrm{~d}$, bFGF induced an approximately fivefold increase in the number of $\mathrm{OL}$ cells expressing $\mathrm{MBP}$ transcripts, and this response was dose dependent with a maximal response at $5 \mathrm{ng} / \mathrm{ml}$ and a decrease to control levels at 50 $\mathrm{ng} / \mathrm{ml}$ (Fig. 7A). In addition, only $15-20 \%$ of the round cells which had not yet regrown processes in control cultures contained MBP transcripts - mostly of the exon 2 type-just as seen with processed OL cells (Fig. 7.A). This ratio was only slightly increased in round OL cells in bFGF-treated cultures, indicating a coupling between the regrowth of processes and enhanced MBP gene expression induced by bFGF. In both control and bFGF conditions, the number of OL cells binding MBP exon 1 probe was slightly higher than the number of OL cells positive with exon 2 probe (Fig. 7.4), suggesting that, at $7 \mathrm{~d}$, the majority of the cells expressing MBP contained mostly MBP exon 2 transcripts.

These experiments with bFGF were performed in the presence of low levels of insulin to minimize signaling of the IGF-I receptors. We then studied the effects of high insulin levels on MBP transcript expression in the presence or absence of bFGF (Fig. 7B). Striking differences between these two growth conditions were seen at $14 \mathrm{~d}$. A high ratio (mean of $80.5 \%$ ) of $\mathrm{OL}$ cells binding the MBP exon 1 probe was found in controls and bFGF-treated cultures (mean $85.5 \%$ ) but, in the absence of bFGF, very few $\mathrm{OL}$ cells expressed MBP exon 2 transcripts, indicating that oligodendrocytes mostly contained mature alternatively spliced MBP transcripts. In contrast, most bFGF-treated OL cells still expressed exon 2-containing MBP transcripts after 2 weeks (Fig. $7 B$ ). When cultures were maintained in bFGF and low insulin for 2 weeks, most MBP transcripts contained exon 2 information, but the ratio of OL cells expressing MBP transcripts was much lower ( $26-40 \%$ in two biopsies; data not shown).
These results suggest that high levels of insulin are needed for expression of MBP transcripts in most cells and that prolonged treatment with bFGF inhibits accumulation of alternatively spliced MBP transcripts and maintains OL cells in a premyelinating stage.

MyTI expression was also enhanced by bFGF in OL cells in vitro (Fig. $6 G, H$ ). bFGF at $5 \mathrm{ng} / \mathrm{ml}$ induced a two- to threefold increase of the number of cells expressing these transcripts at 7 $\mathrm{d}$ (in one biopsy, $10 \%$ of the OL cells contained My TI transcripts in control vs $27 \%$ in bFGF; another biopsy had $29 \%$ OL cells expressing MyTI in control and 62\% in bFGF-treated cultures). Besides, individual cells often showed more intense labeling when compared to cultures treated with $0.5 \mathrm{ng} / \mathrm{ml}$ of bFGF (Fig. $6 G, H)$. Interestingly, bFGF appears to also considerably increase the number of OL+ cells expressing PLP transcripts at $7 \mathrm{~d}$ (from $22 \%$ in control to $77 \%$ in bFGF in one biopsy), indicating that bFGF could enhance early expression of this major myelin gene during oligodendrocyte regeneration in vitro. As with MBP mature transcripts, prolonged bFGF treatment did not allow sustained expression of PLP (the ratio of OL cells expressing PLP went down from $77 \%$ to $29 \%$ between 7 and 14 $\mathrm{d}$ in low insulin). In contrast, $\mathrm{PDGF} \alpha \mathrm{R}$ mRNAs were not influenced by bFGF treatment, staying high even at $14 \mathrm{~d}$ (Fig. 7C). Thus, bFGF strongly enhances expression of the two major myelin genes as well as MyTI in regenerating human oligodendrocytes during the first week in vitro. Eventually, however, IGF-I receptor signaling is required for full differentiation.

\section{Discussion}

In the present study, we show that the myelinated human brain contains cells expressing genes characteristic of an early stage of oligodendrocyte development. The in vivo analysis indicates that $1-2 \%$ of OL cells express PDGF $\alpha \mathrm{R}$ transcripts. This re- 


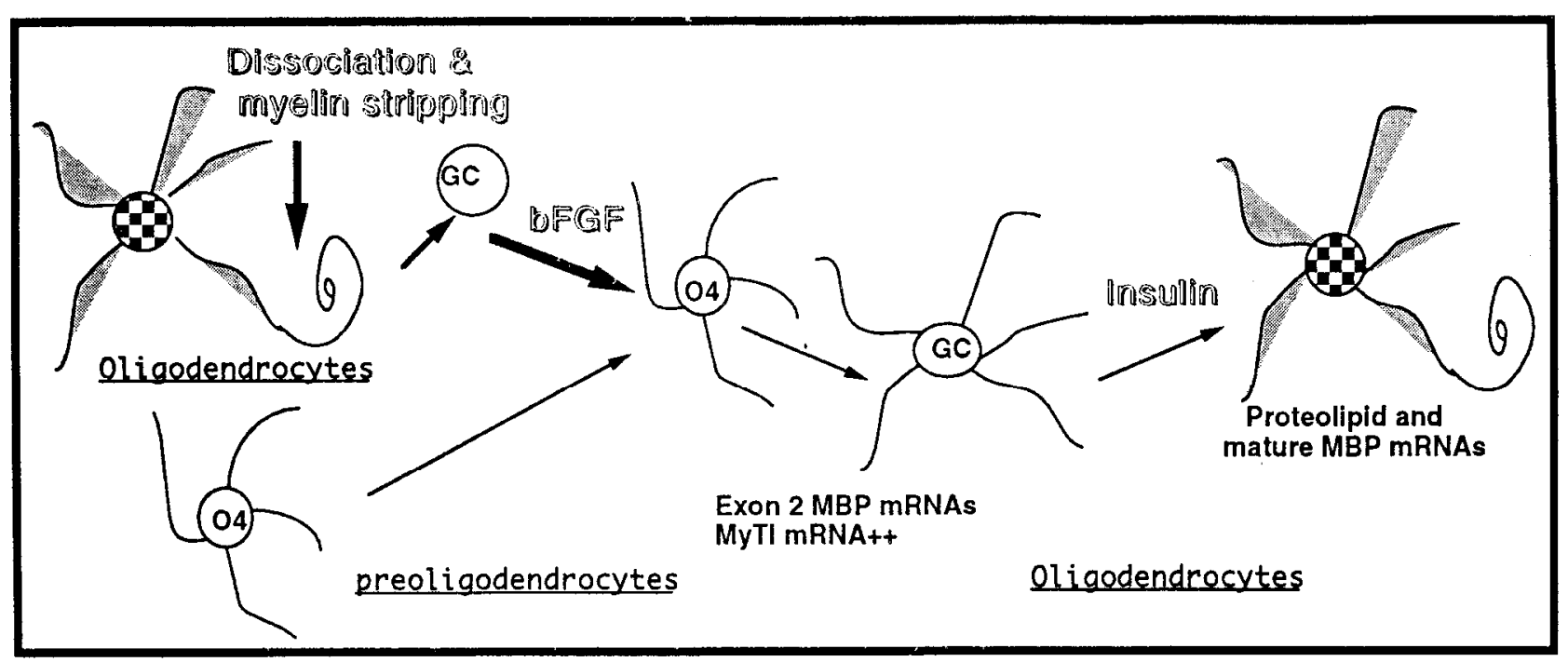

Figure 8. Schematic representation of the regeneration of cells of the adult human oligodendrocyte lineage in vitro. When OL cells are separated from the intact myelinated white matter and put in culture, the large majority of these cells are round GC+/04+ oligodendrocytes stripped of their myelin internodes, while rare preoligodendrocytes with processes can also be identified at $2 \mathrm{~d}$ in vitro. During the first week in vitro, bFGF accelerates process regeneration of OL cells, favors the preoligodendrocyte phenotype, and the expression of MyTI and exon 2 MBP mRNAs isoforms (dotted cell bod ${ }^{\prime}$ ) characteristic of a pre- or remyelinating stage. During the second week in vitro, high insulin levels-triggering the IGF- 1 receptor-iavor expression of PLP transcripts and mature MBP mRNAs characteristic of the myelinating stage (squares in cell body indicate PLP transcripts and dotted matrix reflects the presence of MBP transcripts in the processes). It is unclear why transcripts for PDGF receptor $\alpha$ (not shown in scheme) are highly expressed in most OL cells during the first 2 weeks in vitro although PDGF (and/or bFGF) does not stimulate mitosis in these cells.

ceptor is known to mediate important signaling events in rat oligodendrocyte development. Similarly, 1-2\% of OL cells, which may overlap with those expressing the PDGF $\alpha$ R gene, contain transcripts for MyTI, a transcription factor binding to the promoter of the PLP gene. These putative precursor cells were scattered through the subcortical and cortical regions and, in one of the brain specimens, they were found in clusters in the periventricular region. A much larger proportion of OL cells (15-20\%) expresses early developmental forms of the MBP transcripts (MBP exon 2+) characteristic of the pre- and remyelinating stage. When OL cells were separated from the myelinated white matter and grown in enriched cultures for 1 week in vitro, OL cells more often expressed genes characteristic of the precursor stage than in vivo, while expression of myelin genes was transiently decreased (Fig. 8). There are two possible interpretations for this observation. Either our in in vitro system favored the growth of OL cells at an immature or premyelinating stage, or the majority of OL cells regenerating in vitro were oligodendrocytes that showed enhanced expression of genes characteristic of oligodendrocyte progenitors and transient downregulation of myelin gene transcripts. We favor the latter hypothesis because a large number of GC + cells without processes were detected in the first days in vitro. bFGF, a cytokine known to promote diverse growth processes in neural cells, accelerated the regeneration of human oligodendrocytes in vitro, enhancing the regrowth of processes and favoring the preoligodendrocyte phenotype. bFGF also increases the number of cells expressing early MBP messages as well as transcripts for MyTI and PLP. These events occur in the virtual absence of DNA synthesis or enhancement of cell survival.

In rat postnatal development, $\mathrm{PDGF} \alpha \mathrm{R}$ transcripts are specifically expressed in $\mathrm{O}-2 \mathrm{~A}$ progenitors and not by other glial cells or neurons (Pringle et al., 1992). PDGF $\alpha$ R-positive cells are first seen in the subventricular zone at the corner of lateral ventricles at embryonic day 18 , and are detected later in the forming white matter where cells bearing antigens specific for oligodendrocyte progenitors are also identified (LeVine and Goldman, 1988; Hardy and Reynolds, 1991). PDGF $\alpha$ R-positive cells are also found in the postnatal rat cerebral cortex where cells reacting with $\mathrm{O} 4$ antibodies are present (Yeh et al., 1993). In the adult rodent $\mathrm{CNS}$, oligodendrocyte precursors are rare and can be identified in the intact white matter by their morphology, ultrastructure, antigenic phenotype, and slow renewal rate that can be accelerated in remyelination (McCarthy and Leblond, 1988; Godfraind et al., 1989; Levine et al., 1993; reviewed in Wood and Bunge, 1984; Ludwin et al., 1989). The finding of a population of radiosensitive mitotic glial cells in the adult rat cerebral cortex suggests that cortical regions may also harbor oligodendrocyte precursors (Reyners et al., 1986). The scattered PDGF $\alpha$ R-positive cells detected in the adult rat brain appear to correspond to O-2A adult progenitors and/or their newly differentiated progeny (Pringle et al., 1992). Thus, in both rat and human adult CNS, PDGF $\alpha$ R is expressed in a rare population of cells scattered evenly through the cortex and white matter and probably corresponding to adult O-2A progenitors or preoligodendrocytes.

The distribution of MyTI-positive cells in the adult human CNS is virtually identical to that of PDGF $\alpha$ R. MyTI, a novel member of the zinc finger superfamily, appears also to define a particular stage in oligodendrocyte development (Kim and Hudson, 1992; Armstrong et al., 1993). The expression of MyTI in the nervous system precedes the induction of the PLP gene, which is its presumptive in vivo target. MyTI transcripts and protein are abundantly and specifically expressed in neonatal rat $\mathrm{O}-2 \mathrm{~A}$ progenitors in vitro, with decreasing signals as oligodendrocytes mature (Armstrong et al., 1993). Although the observation of groups of MyTl-and PDGF $\alpha$ R-positive cells in the subventricular zone of one patient needs to be confirmed, it 
suggests that this zone as well as the cortical and subcortical regions could be a source of oligodendrocyte precursor cells in the human adult CNS. The subventricular zone persists in the adult rat CNS as a mitotically active layer that could provide a reserve of cells in pathological conditions when repair is needed (Privat and I eblond, 1972; Morshead and van der Kooy, 1992). The similar rare occurrence and scattered distribution of cells expressing MyTI and/or PDGF $\alpha$ R transcripts in the human myelinated white matter and cortex as well as their overlapping localization in the subventricular zone suggest that these two genes may be expressed in the same cells. Whether or not this population of cells undergoes a slow continuous turnover in the human brain cannot be evaluated.

Many more OL cells of the adult human brain express MBP exon 2 transcripts than PDGF $\alpha \mathrm{R}$ or MyTI. This subpopulation may consist of oligodendrocytes having already assembled myelin internodes and responding to various stimuli by enhanced synthesis of early transcripts. This enhanced expression is not unique to epileptic patients, as the three nonepileptic tissues cxamined showed similar proportions of cells with MBP exon 2 transcripts. Alternatively, such transcripts may be expressed in OL cells that have not yet started to myelinate axons (Allinquant et al., 1991). In favor of this hypothesis is the simultaneous occurrence of a less differentiated stage and an increase in MBP exon 2 transcripts in OL cells treated with bFGF in vitro. Interestingly, MBP exon 2 transcripts were more restricted to the cell body of cultured OL cells while messages detected by the MBP exon 1 probe were already in the processes at $7 \mathrm{~d}$. MBP exon 2 sequences could inhibit mRNA transport in a cis fashion by blocking the binding of a protein involved in active transport of transcripts to the processes. The ultimate destinations of the MBP transcripts are the oligodendrocyte processes where MBP-synthesizing polysomes are placed close to the site of insertion of MBP in the oligodendrocyte and myelin membrane (Colman et al., 1982; Zeller et al., 1985; Trapp et al., 1987; Jordan et al., 1989a; Allinquant et al., 1991). Enhancement of MBP exon 2 expression by bFGF treatment during the first week in vitro appears correlated with a reprogramming of myelination in regenerating human oligodendrocytes in vitro. The bFGF-induced increased expression of MyTI and PLP at $7 \mathrm{~d}$ is probably a reflection of the same reprogramming. With time, however, these regenerating oligodendrocytes will go on to express GC and synthesize mature MBP transcripts and PLP, a process favored by high levels of insulin (Figs. $3 E, 7 B$ ). Similarly, IGF-I increases by 10 -fold the levels of $2^{\prime} 3^{\prime}$-cyclic nucleotide 3 '-phosphohydrolase mRNA in purified rat oligodendrocyte cultures after a week of treatment (Meyer et al., 1993). Taken together, these observations suggest that different growth factors are required to trigger final differentiation of human oligodendrocytes, just as seen in rat oligodendrocyte development (reviewed in Dubois-Dalcq, 1993).

While both rat and human adult $0-2 \mathrm{~A}$ progenitors are characterized in vitro by their complex shape, $\mathrm{O} 4$ reactivity, and absence of vimentin (ffrench-Constant and Raff, 1986; Wolswijk and Noble, 1989; Armstrong et al., 1992; Wren et al., 1992), they differ strikingly in their self-renewal capability in response to $\mathrm{PDGF}$ and/or bFGF. Rat adult $\mathrm{O}-2 \mathrm{~A}$ progenitors derived from optic nerve respond to PDGF AA by mitosis, while PDGF and $b F G F$ together convert thesc slowly dividing adult progenitors into rapidly dividing cells closely resembling neonatal progenitors (Wolswijk et al., 1991; Wolswijk and Noble, 1992). In contrast, cultured human preoligodendrocytes and oligoden- drocytes failed to respond to PDGF AB and AA by mitosis even in the presence of bFGF (Yong et al., 1988; Armstrong et al., 1992; present results). Yet the primate brain expresses both the PDGF ligand and receptors (Sasahara et al., 1991; R. McKinnon, personal communication; present results), indicating that PDGF $\alpha$ R-expressing cells could respond to PDGF. Expression of PDGF $\alpha$ R transcripts in cultured OL cells derived from adult human brain was not upregulated by bFGF as seen in rat neonatal progenitors (McKinnon et al., 1990). The apparent downregulation of PDGF $\alpha$ R expression in most OL cells in vivo contrasts with the presence of transcripts for this receptor in the majority of OL cells regenerating in vitro and suggests an important role for this receptor in regeneration of adult human oligodendrocytes. Assuming that PDGF $\alpha$ R protein is also expressed in human OL cells, PDGF $\alpha \mathrm{R}$ could signal migration rather than mitosis of regenerating oligodendrocytes, a possibility that can be explored in our in vitro system. PDGF is not essential to survival of human adult oligodendrocytes in contrast to developing OL cells, which are much more dependent on survival factors (Barres et al., 1992).

Unlike rodent oligodendrocytes, human OL cells might be able to shift back their differentiation program without reentering the cell cycle. Adult rat spinal cord oligodendrocytes can indeed dedifferentiate into $\mathrm{O} 4$ precursors and actively divide when cocultured with purified rat dorsal root ganglia (DRG) neurons (Wood and Bunge, 1986, 1991). In contrast, coculture with rat DRG neurons or neuroblastoma cell-derived factor(s) does not trigger significant DNA synthesis in human oligodendrocytes and/or preoligodendrocytes (Glaser, Zhou, Bottenstein Dubois-Dalcq, unpublished observations). In rat OL development, forward progression in the lineage can sometimes be reversed, indicating plasticity of OL progenitor cells (Pfeiffer et al., 1993). Similarly, approximately one-third of GC+ human oligodendrocytes maintained for $8 \mathrm{~d}$ in defined medium can shift back to the preoligodendrocyte phenotype after $9 \mathrm{~d}$ in bFGF (Dubois-Dalcq et al., unpublished observations). In MS, oligodendrocytes are destroyed in areas of active myelin breakdown but these lesions are later repopulated by "undifferentiated" oligodendrocytes prior to remyelination. Yet, in these extensive neuropathological studies, no mitotic figures in such cells have been described (reviewed in Prineas et al., 1993), and immunolabeling for the proliferating cell nuclear antigen in MS plaques very rarely stains oligodendrocytes while several endothelial cells and macrophages were labeled (C. S. Raine, personal communication). Also, early lesions often are well remyelinated while subsequent ones may show only partial remyelination.

What then is the origin and pool size of the remyelinating cells in the human CNS? The observations presented here prompt us to propose that there is only a small pool of preoligodendrocytes in the adult human brain that can repair the first wave of lesions in a demyelinating disease. These cells may not be able to divide but may migrate toward naked axons, possibly through PDGF signaling, and be induced to differentiate. Alternatively, they may respond to an as yet unidentified factor by mitosis. On the other hand, human oligodendrocytes show remarkable phenotypic plasticity as, once deprived of their myelin sheath, they may revert to a preoligodendrocyte phenotype and reset their myclination program. Such a process could be accelcrated by bFGF, whose synthesis might be enhanced in and around demyelinating lesions. In experimental demyelination, an increase in expression of aFGF, a related member of the FGF 
family, coincides with cell repopulation preceding remyelination (lourbah et al., 1992).

The reexpression or enhanced expression of exon $2 \mathrm{MBP}$ transcripts in regencrating oligodendrocytes may turn out to be a key step in efficient repair of myelin in MS. Exon $2 \mathrm{MBP}$ transcripts are indeed dramatically increased around demyelinating lesions in a virus-induced demyelinating disease of mice, and this enhanced MBP expression precedes CNS remyelination (Kristensson, 1986; Kristensson et al., 1986; Jordan et al., 1989b, 1990). Yet the immune system may react to these regenerating events, as evidenced by recent studies in human. Human MBPspecific $T$ cell lines (TCLs) recognizing immunodominant epitopes of MBP can be established from both MS patients and controls. $T$ cell lines specific for MBP exon 2 peptide were derived from three MS patients as well as from one healthy control, indicating that autoantigens other than the major isoforms of myelin proteins could be potential targets of a $\mathrm{T}$ cellmediated immune process (Voskuhl et al., 1993a). When three members of a multiplex family were examined, the one member with chronic progressive MS showed the highest frequency of exon 2-specific TCLs as compared to a normal and a less progressive case in the family (Voskuhl et al., 1993b). These differences in MBP exon 2 responsiveness were observed only with this specific peptide and not with the mature 18.5 K MBP devoid of exon 2 sequences. Thus, the immune response to MBP exon 2 peptide may contribute to disease progression in MS by interrupting the process of remyelination or attacking regenerating oligodendrocytes and/or freshly made myelin. Our observations point to the importance of understanding mechanisms of oligodendrocyte regeneration at the cellular and molecular levels to provide an integrated picture on how myelin can be repaired and maintained in the face of an ever evolving immune response to myelin proteins.

\section{References}

Allinquant B, Staugaitis SM, D'Urso D, Colman DR (1991) The ectopic expression of myelin basic protein isoforms in Shiverer oligodendrocytes: implications for myelinogenesis. J Cell Biol 113:393403.

Alvord EC Jr, Rose LM, Richards TL (1992) Chronic experimental allergic encephalomyelitis as a model of multiple sclerosis. In: Myelin: biology and chemistry (Martenson RE, ed), pp 849-892. Boca Raton: CRC.

Armstrong K, Friedrich VL, Holmes KV, Dubois-Dalcq M (1990a) In vitro analysis of the oligodendrocyte lineage in mice during demyelination and remyelination. $\mathrm{J}$ Cell Biol 111:1183-1195.

Armstrong R, Harvath L, Dubois-Dalcq M (1990b) Astrocytes and oligodendrocyte-type 2 astrocyte glial progenitors migrate toward distinct molecules. J Neurosci Res 2:400-407.

Armstrong R, Dorn HH, Kufta CV, Friedman E, Dubois-Dalcq ME (1992) Pre-oligodendrocytes from adult human CNS. J Neurosci 12: 1538-1547.

Armstrong R, Kim JG, Hudson LD (1993) MyTI, a DNA-binding protein in oligodendrocyte lineage cells. Trans Am Soc Neurochem 24:218.

Bansal RA, Warrington A, Gard AL, Ranscht B, Pfeiffer SE (1989) Multiple and novel specificities of monoclonal antibodies $\mathrm{O} 1, \mathrm{O} 4$ and $\mathrm{K}-\mathrm{m}-\mathrm{Ab}$ used in the analysis of oligodendrocyte development. J Neurosci Res 24:548-557.

Barres BA, Kart IK, Coles HSR, Burne JF, Voyvodic JT, Richardson WD, Raff MC (1992) Cell death and control of cell survival in the oligodendrocyte lineage. Cell 70:31-46.

Bogler O, Wren D, Barnett SC, Land H, Noble M (1990) Cooperation between two growth factors promotes extended self-renewal and inhibits differentiation of oligodendrocyte-type-2 astrocyte (O-2A) progenitor cells. Proc Natl Acad Sci USA 87:6368-6372.

Bradley DJ, Towle HC, Young WS III (1992) Spatial and temporal expression of $\mathrm{a}$ and $\mathrm{b}$ thyroid hormone receptor mRNAs, including the $b 2$ subtype, in the developing mammalian nervous system. J Neurosci 12:2288-2302.

Cameron RS, Rakic P (1991) Glial cell lineage in the cerebral cortex: a review and synthesis. Glia 4:124-137.

Campagnoni AT, Pribyl TM, Campagnoni CW, Kampf K, AmurUmarjee S, Landry CF, Handley VW, Newman SL, Garbay B, Kitamura K (1993) Structure and developmental regulation of GolliMBP, a $105 \mathrm{~kb}$ gene that encompasses the myelin basic protein gene and is expressed in cells in the oligodendrocyte lineage in the brain. J Biol Chem 268:4930-4938.

Carson JH, Nielson ML, Barbarese E (1983) Developmental regulation of myelin basic protein expression in mouse brain. Dev Biol 96:485492.

Carson MJ, Behringer RR, Brinster RL, McMorris FA (1993) Insulinlike growth factor increases brain growth and central nervous system myelination in transgenic mice. Neuron 10:729-740.

Colman DR, Kreibich G, Frey AB, Sabatini DD (1982) Synthesis and incorporation of myelin polypeptides into CNS myelin. J Cell Biol 95:598-608.

Diehl HJ, Schaich M, Budzinski RM, Stoffel W (1986) Individual exons encode the integral membrane domains of human myelin proteolipid protein. Proc Natl Acad Sci USA 83:9807-9811.

Dubois-Dalcq M (1987) Characterization of a slowly proliferative cell along the oligodendrocyte differentiation pathway. EMBO J 6:25872595.

Dubois-Dalcq M (1993) The developmental and regeneration of CNS myelin forming cells. In: Glia and neuroglia interactions (FRF International School of Neuroscience, eds), in press. New York: Thieme.

Dubois-Dalcq M, Armstrong R (1990) The cellular and molecular events of the central nervous system remyelination. Bioessays 12: $569-581$.

Dubois-Dalcq M, Armstrong R (1992) The oligodendrocyte lineage during myelination and remyelination. In: Myelin: biology and chemistry (Martenson RE, ed), pp 81-122. Boca Raton: CRC.

Dubois-Dalcq M, Behar T. Hudson L, Lazzarini RA (1986) Emergence of three myelin proteins in oligodendrocytes cultured without neurons. J Cell Biol 102:384.

Eccleston PA, Silberberg DH (1985) Fibroblast growth factor is a mitogen for oligodendrocytes in vitro. Dev Brain Res 21:315-318.

Espinosa de los Monteros A, Zhang M, de Vellis J (1993) O-2A progenitor cells transplanted into the neonatal rat brain develop into oligodendrocytes but not astrocytes. Proc Natl Acad Sci USA 90:5054.

Fazakerley JK, Buchmeier MJ (1992) Virus induced demyelination. In: Myelin: biology and chemistry (Martenson RE, ed), pp 893-934. Boca Raton: CRC.

ffrench-Constant C, Raff MC (1986) Proliferating bipotential glial progenitor cells in adult rat optic nerve. Nature 319:499-502.

Godfraind C, Friedrich V, Holmes K, Dubois-Dalcq M (1989) In vivo analysis of glial cell phenotypes during a viral demyelinating disease in mice. J Cell Biol 109:2405-2416.

Hardy R, Reynolds R (1991) Proliferation and differentiation potential of rat forebrain oligodendroglial progenitors both in vitro and in vivo. Development 111:1061-1080.

Hart IK, Richardson WD, Heldin C-H, Westermark B, Raff MC (1989) PDGF receptors on cells of the oligodendrocyte-type-2 astrocyte $(\mathrm{O}-$ 2A) cell lineage. Development 105:595-603.

Hudson LD (1990) Molecular biology of myelin proteins in the central and peripheral nervous system. Semin Neurosci 2:483-496.

Hunter SF, Bottenstein JE (1991) O-2A glial progenitors from mature brain respond to CNS neuronal cell line-derived growth factors. J Neurosci Res 28:574-582.

Jordan C (1990) In situ hybridization in cells and tissue sections: a study of myelin gene expression during CNS myelination and remyelination. In: In situ hybridization histochemistry (Chessclet M-F, ed), pp 39-70. Boca Raton: CRC.

Jordan C, Fredrich V Jr, Dubois-Dalcq M (1989a) In situ hybridization analysis of myelin gene transcripts in developing mouse spinal cord. J Neurosci 9:248-257.

Jordan C, Friedrich V Jr, Godfraind C, Holmes K, Dubois-Dalca M (1989b) Expression of viral and myelin gene transcripts in a murine demyelinating disease caused by a coronavirus. Glia 2:318-389.

Jordan C, Friedrich VL Jr, de Ferra F, Weismiller DG, Holmes KV, Dubois-Dalcq M (1990) Differential exon expression in myelin basic 
protein transcripts during central nervous system (CNS) remyelination. Cell Mol Neurobiol 10:3-18.

Kamholz J, Wrabetz L (1992) Molecular genetics of myelin basic protein. In: Myelin: biology and chemistry (Martenson RE, ed), pp 367-385. Boca Raton: CRC.

Kamholz J, de Ferra F, Puckett C, Lazzarini R (1986) Identification of three forms of human basic protein by cDNA cloning. Proc Natl Acad Sci USA 83:4962-4906.

Kamholz J, Spielman R, Gogolin K, Modi W, O'Brien S, Lazzarini R (1987) The human myelin-basic-protein gene: chromosomal localization and RFLP analysis. Am J Hum Genet 40:365-373.

Kamholz J. Toffenetti J, Lazzarini R (1988) Organization and expression of the human myelin basic protein gene. $J$ Neurosci Res 21: $62-70$.

Kim JG, Hudson LD (1992) Novel member of the zinc finger superfamily: a $\mathrm{C} 2-\mathrm{HC}$ finger that recognizes a glia-specific gene. Mol Cell Biol 12:5632-5639.

Kristensson K, Zeller N, Lazzarini RA, Dubois-Dalcq M (1986a) Expression of myelin basic protein gene in the developing rat brain as revealed by in situ hybridization. J Histochem Cytochem 34:467473.

Kristensson K, Holmes K, Zeller N, Lazzarini RA, Dubois-Dalcq M (1986b) Increased levels of myelin basic protein transcripts in virusinduced demyelination. Nature 322:544-547.

Lee K-H. Bowen-Pope DF, Reed RR (1990) Isolation and characterization of the a platelet-derived growth factor receptor from rat olfactory epithelium. Mol Cell Biol 10:2237-2246.

Levine J, Stincone F, Lee YS (1993) Development and differentiation of glial precursor cells in the rat cerebellum. Glia 7:307-321.

LeVine SM, Goldman JE (1988) Spatial and temporal patterns of oligodendrocyte differentiation in rat cerebrum and cerebellum. $J$ Comp Neurol 277:441-455.

Levison SW, Goldman JE (1993) Both oligodendrocyles and astrocytes develop from progenitors in the subventricular zone of postnatal rat forebrain. Neuron 2:201-212.

Ludwin SK (1979) An autoradiographic study of cellular proliferation in remyelination of the central nervous system. Am J Pathol 95:683696.

Ludwin SK (1989) Evolving concepts and issues in remyelination. Dev Neurosci 11:140-148.

McCarthy GF, Leblond CP (1988) Radioautographic evidence for slow astrocyte turnover and modest oligodendrocyte production in the corpus callosum of adult mice infused with ${ }^{3} \mathrm{H}$-thymidine. J Comp Neurol 271:589-603.

McKinnon RD, Matsui T, Dubois-Dalcq M, Aaronson SA (1990) FGF modulates the PDGF-driven pathway of oligodendrocyte development. Neuron 5:603-614.

McKinnon R, Matsui T, Aranda M, Dubois-Dalcq M (1991) A role for fibroblast growth factor in oligodendrocyte development. Ann NY Acad Sci 638:378-386.

McKinnon R, Smith C. Behar T, Smith T, Dubois-Dalcq M (1993) Distinct effects of bFGF and PDGF on oligodendrocyte progenitor cells. Glia 7:245-254.

McMorris FA, Dubois-Dalcq M (1988) Insulin-like growth factor I promotes cell proliferation and oligodendroglial commitment in rat glial progenitor cells developing in vitro. J Neurosci Res 21:199-209.

McMorris FA. Smith T. DeSalvo S, Furlanetto R (1986) Insulin-like growth factor I/somatomedin C: a potent inducer of oligodendrocyte development. Proc Natl Acad Sci USA 83:822-826.

Meyer RD, Marchetti N, McMorris FA (1993) IGF-I increases CNP activity and mRNA per oligodendrocyte. Trans Am Soc Neurochem 24:261.

Morshead CM, van der Kooy D (1992) Postmitotic death is the fate of constitutively proliferating cells in the subependymal layer of the adult mouse brain. J Neurosci 12:249-256.

Noble M, Murray K, Stroobant P, Waterfield MD, Riddle P (1988) Platelet-derived growth factor promotes division and motility and inhibits premature differentiation of the oligodendrocyte type-2 astrocyte progenitor cell. Nature 333:560-562.

Pfeiffer SE, Warrington AE, Bansal R (1993) The oligodendrocyte and its many processes. Trends Cell Biol 3:191-197.

Pribyl TM, Campagnoni CW, Kampf K, Kashima T, Handley VW, Mc Mahon J, Campagnoni AT (1993) The human myelin basic protein gene is included within a 179-kilobase transcription unit: expression in the immune and central nervous systems. Proc Natl Acad Sci USA 90:10695-10699.
Prineas JW, Barnard RO, Kwon EE, Sharer LR, Cho ES (1993) Multiple sclerosis: remyelination of nascent lesions. Ann Ncurol 33:137151.

Pringle N, Collarini EJ, Mosley MJ, Heldin CH, Westermark B, Richardson WD (1989) PDGF A chain homodimers drive proliferation of bipotential (O-2A) glial progenitor cells in the developing rat optic nerve. EMBO J 8:1049-1056.

Pringle NP, Mudhar HS, Collarini EJ, Richardson WD (1992) PDGF receptors in the rat CNS: during late neurogenesis, PDGF alphareceptor expression appears to be restricted to glial celis of the oligodendrocyte lineage. Development 115:535-551.

Privat A, LeBlond CP (1972) The subependymal layer and the neighhoring region in the brain of the young rat. J Comp Neurol 146:277302.

Raff MC (1989) Glial cell diversification in the rat optic nerve. Science 243:1450-1456

Raff MC, Miller RH, Noble M (1983) A glial progenitor cell that develops in vitro into an astrocyte or an oligodendrocyte depending on culture medium. Nature 303:390-396.

Raff MC, Lillien LE, Richardson WD, Burne JF, Noble MD (1988) Platelet-derived growth factor from astrocytes drives the clock that times oligodendrocyte development in culture. Nature 333:560-565.

Raine CS, Moore GR, Hintzen R, Traugott U (1988) Induction of oligodendrocyte proliferation and remyelination after chronic demyelination. Lab Invest 59:467-476.

Ranscht B, Clapshaw PA, Price J, Noble M, Seifert W (1982) Development of oligodendrocytes and Schwann cells studied with a monoclonal antibody against galactocerebroside. Proc Natl Acad Sci USA 79:2709-2713.

Reyners H, Gianfelici de Reyners E, Regniers L, Maisin J-R (1986) ^ glial progenitor cell in the cerebral cortex of the adult rat. J Neurocytol 11:54-62.

Richardson WD, Pringle N, Mosley MJ, Westermark B, Dubois-Dalcq M (1988) A role for platelet-derived growth factor in normal gliogenesis in the central nervous system. Cell 53:309-319.

Richardson WD, Raff M. Noble M (1990) The oligodendrocyte-type2-astrocyte lineage. Semin Neurosci 2:445-454.

Ritchie JM (1984) Physiological basis of conduction in myelinated nerve fibers. In: Myelin (Morell, ed), pp 11 7-146. New York: Plenum.

Sasahara M, Fries JWU, Raines EW, Gown AM, Westrum LE, Frosch MP, Bonthron DT, Ross R, Collins T (1991) PDGF B-chain in neurons of the central nervous system, posterior pituitary, and in a transgenic model. Cell 64:217-227.

Shu S, Ju G, Fan L (1988) The glucose oxidase-DAB-nickel method in peroxidase histochemistry of the nervous system. Neurosci Lett 85:169-171.

Sommer I, Schachner M (1981) Monoclonal antibodies (Ol to O4) to oligodendrocyte cell surfaces: an immunocytochemical study in the central nervous system. Dev Biol 83:311-327.

Tourbah A, Baron-Van Evercooren A, Oliver L, Raulais D, Jeanny JC, Gumpel M (1992) Endogenous aFGF expression and cellular changes after a demyelinating lesion in the spinal cord of adult normal mice: immunohistochemical study. J Neurosci Res 33:47-59.

Trapp BD, Moeuch T, Pulley M, Barbosa E, Tenekoon G, Griffith J (1987) Spatial segregation on mRNA encoding myelin-specific proteins. Proc Natl Acad Sci USA 84:7773-7777.

Vick RS, DeVries GH (1992) Mitotic potential of adult rat oligodendrocytes in culture. $J$ Neurosci Res 33:68-74.

Vogel US, Reynolds R, Thompson RJ, Wilkin GP (1988) Expression of the $2^{\prime}, 3^{\prime}$-cyclic nucleotide $3^{\prime}$-phosphohydrolase gene and immunoreactive protein in oligodendrocytes as revealed by in situ hybridization and immunofluorescence. Glia 1:184.

Voskuhl RR, McFarlin DE, Stone R, McFarland HF (1993a) T-lymphocyte recognition of a portion of myelin basic protein encoded by an exon expressed during myelination. J Neuroimmunol 42:199-208.

Voskuhl RR, McFarlin DE, Rhame L, Deibler G, Stone R, Maloni H, McFarland HF (1993b) A novel candidate autoantigen in a multiplex family with multiple sclerosis: T-lymphocytes specific for an MBP epitope unique to myelination are as prevalent as epitopes within 18.5kd MBP. J Neuroimmunol 46:137-144.

Warrington A, Barbarese E, Pfeiffer SE (1993) Differential myelinogenic capacity of specific developmental stages of the oligodendrocyte lineage upon transplantation into hypomyelinating hosts. J Neurosci Res 34:1-13.

Wolswijk G, Noble M (1989) Identification of an adult-specific glial progenitor cell. Development 105:387-400. 
Wolswijk G, Noble M (1992) Cooperation between PDGF and FGF converts slowly dividing $\mathrm{O}-2 \mathrm{~A}$ adult progenitor cells to rapidly dividing cells with characteristics of $\mathrm{O}-2 \mathrm{~A}$ perinatal progenitor cells. $\mathrm{J}$ Cell Biol 118:889-900.

Wolswijk G. Riddle PN. Noble M (1991) Platelet-derived growth factor is mitogenic for $\mathrm{O}-2 \mathrm{~A}$ adult progenitor cells. Glia 4:495-503.

Wood PM, Bunge RP (1984) The biology of the oligodendrocyte. In Oligodendroglia (Norton WT, ed), pp 1-46. New York: Plenum.

Wood PM, Bunge RP (1986) Evidence that axons are mitogenic for oligodendrocytes isolated from adult animals. Nature 320:756-758.

Wood PM. Bunge RP (1991) The origin of remyelinating cells in the adult central nervous system: the role of the mature oligodendrocyte. Glia 4:225-232.

Wren D. Wolswijk G. Noble M (1992) In vitro analysis of the origin and maintenance of O-2A adult progenitor cells. J Cell Biol 116:167176.
Yeh H-J, Ruit KG, Wang Y-X. Parks WC, Snider WD, Deuel TF (1991) PDGF A-chain gene is expressed by mammalian neurons during development and in maturity. Cell 64:209-216.

Yeh H-J, Silos-Santiago 1, Wang Y-X, George RJ (1993) Developmental expression of the platelet-derived growth factor a-receptor gene in mammalian central nervous system. Proc Natl Acad Sci USA 90:1952-1956.

Yong VW. Antel JP (1992) Culture of glial cells from human brain biopsies. In: Protocols for neural cell culture (Fedoroff S, Richardson A. eds), pp 81-95. New Jersey: Humana.

Yong VW, Kim SU, Kim MW, Shin DH (1988) Growth factors for human glial cells in culture. Glia 1:113-123.

Zeller NK, Behar TN. Dubois-Dalcq M. Lazzarini RA (1985) The timely expression of myelin basic protein gene in cultured rat brain oligodendrocytes is independent of continuous neuronal influences. J Neurosci 5:2955-2962. 